\title{
Greenhouse gas balance of cropland conversion to bioenergy poplar short-rotation coppice
}

\author{
S. Sabbatini ${ }^{1}$, N. Arriga $^{2}$, T. Bertolini ${ }^{3}$, S. Castaldi $^{3}$, T. Chiti ${ }^{1}$, C. Consalvo ${ }^{1}$, S. Njakou Djomo ${ }^{4,5}$, B. Gioli ${ }^{6}$, \\ G. Matteucci ${ }^{7}$, and D. Papale ${ }^{1}$ \\ ${ }^{1}$ University of Tuscia, Department for Innovation in Biological, Agro-food and Forest systems, \\ Via S. Camillo de Lellis snc, 01100 Viterbo (VT), Italy \\ ${ }^{2}$ University of Antwerp, Department of Biology, Research Group of Plant and Vegetation Ecology, \\ Universiteitsplein 1, 2610 Wilrijk, Belgium \\ ${ }^{3}$ Second University of Naples, Department of Environmental, Biological, Pharmaceutical Sciences \\ and Technologies, Via Vivaldi 43, 81100 Caserta (CE), Italy \\ ${ }^{4}$ Hasselt University, Department of Economic, Research Group of Environmental Economics, \\ Martelarenlaan 42, 3500 Hasselt, Belgium \\ ${ }^{5}$ Aarhus University, Department of Agroecology, Blichers Alle 20, 8830, Tjele, Denmark \\ ${ }^{6}$ Institute of Biometeorology, National Research Council, Via G. Caproni 8, 50145 Firenze (FI), Italy \\ ${ }^{7}$ Institute for Agricultural and Forestry Systems in the Mediterranean, National Research Council, \\ Via Cavour 4-6, 87036 Rende (CS), Italy
}

Correspondence to: S. Sabbatini (simone.sabbatini@unitus.it)

Received: 10 April 2015 - Published in Biogeosciences Discuss.: 28 May 2015

Revised: 11 December 2015 - Accepted: 14 December 2015 - Published: 15 January 2016

\begin{abstract}
The production of bioenergy in Europe is one of the strategies conceived to reduce greenhouse gas (GHG) emissions. The suitability of the land use change from a cropland (REF site) to a short-rotation coppice plantation of hybrid poplar (SRC site) was investigated by comparing the GHG budgets of these two systems over 24 months in Viterbo, Italy. This period corresponded to a single rotation of the SRC site. The REF site was a crop rotation between grassland and winter wheat, i.e. the same management of the SRC site before the conversion to short-rotation coppice. Eddy covariance measurements were carried out to quantify the net ecosystem exchange of $\mathrm{CO}_{2}\left(F_{\mathrm{CO}_{2}}\right)$, whereas chambers were used to measure $\mathrm{N}_{2} \mathrm{O}$ and $\mathrm{CH}_{4}$ emissions from soil. The measurements began 2 years after the conversion of arable land to SRC so that an older poplar plantation was used to estimate the soil organic carbon (SOC) loss due to SRC establishment and to estimate SOC recovery over time. Emissions from tractors and from production and transport of agricultural inputs $\left(F_{\text {MAN }}\right)$ were modelled. A GHG emission offset, due to the substitution of natural gas with SRC biomass, was credited to the GHG budget of
\end{abstract}

the SRC site. Emissions generated by the use of biomass $\left(F_{\mathrm{EXP}}\right)$ were also considered. Suitability was finally assessed by comparing the GHG budgets of the two sites. $\mathrm{CO}_{2}$ uptake was $3512 \pm 224 \mathrm{~g} \mathrm{CO}_{2} \mathrm{~m}^{-2}$ at the SRC site in 2 years, and $1838 \pm 107 \mathrm{~g} \mathrm{CO}_{2} \mathrm{~m}^{-2}$ at the REF site. $F_{\text {EXP }}$ was equal to $1858 \pm 240 \mathrm{~g} \mathrm{CO}_{2} \mathrm{~m}^{-2}$ at the $\mathrm{REF}$ site, thus basically compensating for $F_{\mathrm{CO}_{2}}$, while it was $1118 \pm 521 \mathrm{~g} \mathrm{CO}_{2} \mathrm{~m}^{-2}$ at the SRC site. The SRC site could offset $379.7 \pm 175.1 \mathrm{~g}$ $\mathrm{CO}_{2} \mathrm{eq} \mathrm{m}^{-2}$ from fossil fuel displacement. Soil $\mathrm{CH}_{4}$ and $\mathrm{N}_{2} \mathrm{O}$ fluxes were negligible. $F_{\text {MAN }}$ made up 2 and $4 \%$ in the GHG budgets of SRC and REF sites respectively, while the SOC loss was $455 \pm 524 \mathrm{~g} \mathrm{CO}_{2} \mathrm{~m}^{-2}$ in 2 years. Overall, the REF site was close to neutrality from a GHG perspective $\left(156 \pm 264 \mathrm{~g} \mathrm{CO}_{2} \mathrm{eq} \mathrm{m}^{-2}\right)$, while the SRC site was a net sink of $2202 \pm 792 \mathrm{~g} \mathrm{CO}_{2} \mathrm{eq} \mathrm{m}^{-2}$. In conclusion the experiment led to a positive evaluation from a GHG viewpoint of the conversion of cropland to bioenergy SRC. 


\section{Introduction}

In the current regulation concerning energy and climate change policies, the European Union (EU) established two targets for 2020: (i) a reduction of $20 \%$ of greenhouse gas (GHG) emissions relative to the levels of 1990, and (ii) a share of $20 \%$ renewable energy use in gross final energy consumption (European Commission, 2007, 2008). For Italy the latter is set at $17 \%$ (European Commission, 2009).

In the context of climate mitigation, bioenergy crops are expected to play a key role in the renewable energy supply in the EU in the coming decades (Djomo et al., 2013). Shortrotation coppices (SRC) of fast-growing trees, and especially of poplar (Populus spp.), are a promising culture in this context. SRC has the potential to reduce GHG emissions to the atmosphere during both its production (by capturing $\mathrm{CO}_{2}$ from the atmosphere and storing it in above-ground biomass and soil) and use (by avoiding $\mathrm{CO}_{2}$ emissions from fossil fuel burning). However, the management of SRC requires energy inputs and the use of fossil fuels. Furthermore, the land use change (LUC) to SRC may imply losses of soil organic carbon (SOC) at the point of its installation (Don et al., 2012), especially in C-rich soils. For these reasons, converting land for SRC production may alter the equilibrium of the existing ecosystems, causing an impact that in some cases can counterbalance the positive effects on climate mitigation of the supposedly carbon-neutral SRC systems (Abbasi and Abbasi, 2009; Zona et al., 2013; see also Crutzen et al., 2008; Fargione et al., 2008, on bioenergy crops in general). A recent study (Djomo et al., 2011), however, showed that poplar and willow SRC biomass use can save up to 80$90 \%$ of GHG emissions compared to using coal for energy production. Studies on the climate mitigation potential of poplar cultivations constitute an important tool in supporting energy and environmental policies on different scales. In recent years researchers have approached poplar SRCs from different perspectives: ecological (Jaoudé et al., 2011; Zhou et al., 2013), economic (Strauss and Grado, 1997; Mitchell et al., 1999; El Kasmioui and Ceulemans, 2012, 2013), and related to energy production and different environmental aspects (Jungmeier and Spitzer, 2001; Cherubini et al., 2009; Davis et al., 2009; Nassi o Di Nasso et al., 2010; Arevalo et al., 2011; Don et al., 2012; Dillen et al., 2013; Djomo et al., 2013). However, these studies often used different approaches, making it difficult to compare their results (Migliavacca et al., 2009; Djomo et al., 2011). Furthermore, emphasis was mainly placed on emissions from fossil fuels rather than on the biogenic emissions due to the LUC (Djomo et al., 2013). Including the different contributions of the LUC in the assessments of emission savings related to energy crops is crucial (Davis et al., 2009). A full GHG budget based on long-term measurements of $\mathrm{CO}_{2}$ and non- $\mathrm{CO}_{2}$ GHGs via eddy covariance (EC) methodology (Aubinet et al., 2012) and soil chamber measurements (Allard et al., 2007) can be used to assess the GHG mitigation potential of land conver- sion to SRC (Byrne et al., 2007; Ceschia et al., 2010). Several authors (e.g. Ceschia et al., 2010; Osborne et al., 2010) highlighted the need for a more consistent number of studies on GHG budgets, including different types of management practices, climate conditions, and soil characteristics, in order to reduce the uncertainty in GHG budgets on a large scale (Smith et al., 2010). A GHG budget approach was used by Gelfand et al. (2011) in a conversion of unmanaged lands to herbaceous biofuel crops in the US. In Europe, Zona et al. (2013) estimated the GHG balance in the first year after the conversion from agricultural lands to a poplar SRC in Belgium, focusing on biogenic contributions. The present study considered the conversion of a cropland (hereafter referred to as "REF site") to a poplar SRC (hereafter referred to as "SRC site") for bioenergy production in the Mediterranean area (Viterbo, Central Italy). The aim was to extend the GHG balance to emissions generated by field management and to the offset of GHG from fossil fuel substitution. The number of studies on SRC systems cultivated in Mediterranean areas, where water availability can constitute a limiting factor for biomass yield and thus climate mitigation (Cherubini et al., 2009), is limited. Given that the climate change mitigation potential of energy crops is the main reason for subsidies to arable land conversion, our study aimed to assess the suitability of the LUC to SRC in terms of the mitigation of GHG emissions.

\section{Materials and methods}

\subsection{GHG budgets assessment}

The GHG budgets were calculated for the SRC and for the REF sites on a temporal basis of 2 years ( 24 months), corresponding to the second rotation cycle of the SRC site. They included several positive and negative GHG contributions, with the following sign convention: a positive flux indicates a release into the atmosphere, while a negative flux represents an uptake from the atmosphere. In both cases the boundary of the system was set to the farm level. For the SRC site, the net GHG budget $\left(B_{\mathrm{SRC}}\right)$ was calculated as the algebraic sum of all GHG contributions as indicated in Eq. (1):

$$
\begin{aligned}
& B_{\mathrm{SRC}}=F_{\mathrm{CO}_{2}}+F_{\mathrm{CH}_{4}}+F_{\mathrm{N}_{2} \mathrm{O}}+F_{\mathrm{MAN}}+F_{\mathrm{SOC}} \\
& +F_{\mathrm{SAV}}+F_{\mathrm{EXP}} .
\end{aligned}
$$

In Eq. (1), $F_{\mathrm{CO}_{2}}$ represents the flux of $\mathrm{CO}_{2}$, i.e. the net ecosystem exchange (NEE) of $\mathrm{CO}_{2}$, while $F_{\mathrm{CH}_{4}}$ and $F_{\mathrm{N}_{2} \mathrm{O}}$ represent the biogenic methane and nitrous oxide soilatmosphere exchanges. $F_{\text {MAN }}$ includes the GHG emissions related to the management of the SRC site, and $F_{\mathrm{SOC}}$ is the loss of soil organic carbon content due to the installation of the cuttings. $F_{\mathrm{SAV}}$ represents the GHG offsets, i.e. GHG emissions avoided due to the substitution of natural gas by biomass in heat production, and $F_{\mathrm{EXP}}$ represents the biomass 
exported from the site at the end of the cycle and re-emitted as $\mathrm{CO}_{2}$ at burning.

Similarly, the net GHG budget of the REF site ( $\left.B_{\mathrm{REF}}\right)$ was estimated with the algebraic sum indicated in Eq. (2), where unlike in Eq. (1), there is no $F_{\mathrm{SOC}}$ and $F_{\mathrm{SAV}}$, and $F_{\mathrm{EXP}}$ is the portion of the exported biomass that returns to the atmosphere as $\mathrm{CO}_{2}$ or $\mathrm{CH}_{4}$ :

$B_{\mathrm{REF}}=F_{\mathrm{CO}_{2}}+F_{\mathrm{CH}_{4}}+F_{\mathrm{N}_{2} \mathrm{O}}+F_{\mathrm{MAN}}+F_{\mathrm{EXP}}$.

All the contributions of $B_{\mathrm{SRC}}$ and $B_{\mathrm{REF}}$ were expressed as $\mathrm{CO}_{2}$-equivalent $\left(\mathrm{CO}_{2} \mathrm{eq}\right)$ fluxes per unit of surface, as the functional unit of the study was $1 \mathrm{~m}^{2}$ of land. Finally, the net GHG cost or benefit of converting the cropland to an SRC plantation was calculated by comparing $B_{\mathrm{SRC}}$ and $B_{\mathrm{REF}}$. Displacement of food and feed production related to SRC cultivation on cropland was beyond the scope of this study.

\subsection{Site description}

Two sites close to each other located on a private farm (Gisella ed Elena Ascenzi S.A.A.S.) in Castel d'Asso, Viterbo, Italy (coordinates: $42^{\circ} 22^{\prime} \mathrm{N}, 12^{\circ} 01^{\prime} \mathrm{E}$ ), were selected during summer 2011. Two EC towers were installed at the two sites to measure the exchanges of $\mathrm{CO}_{2}$ and $\mathrm{H}_{2} \mathrm{O}$ between the ecosystem and the atmosphere following the methodology reported in Aubinet et al. (2000). The climate of the area is Mediterranean, with a yearly average rainfall of $766 \mathrm{~mm}$, mean temperature of $13.76^{\circ} \mathrm{C}$, and weak summer aridity in July-August (Blasi, 1993). The SRC site was a 2-year rotation-cycle-managed poplar plantation of 11 ha planted in 2010 to produce biomass for energy (heat). Poplar cultivar was Populus x canadensis - clone AF2, selected in Alasia Franco Vivai's nurseries. According to the regional law (Rural Development Programme of Latium 2007-2013, Latium Region, 2015), 12 years is the maximum period during which to obtain subsidies for SRC, and this corresponded to the time the farmer decided to cultivate the SRC site (A. Trani, personal communication, 2012). For that reason the calculations of the present study will be based on a 24-month period taking into account the 12-year lifespan for the SRC site. The site was previously managed with a 2-year rotation between a clover grassland (Trifolium incarnatum L.) mixed with ryegrass (Lolium multiflorum Lam.) and winter wheat (Triticum aestivum L. emend. Fiori et Paol.). The REF site was a 9 ha grassland-winter-wheat rotation located a short distance away $(300 \mathrm{~m})$. As this site had identical land use and management to the SRC site before the installation of the poplars, it was selected to assess the GHG effects of the LUC. GHG balances were calculated over 24 months at both sites. However, these 24-month periods did not completely overlap, as the two cultivations had different starting times: for the SRC site the GHG budget estimation went from 12 January 2012 (immediately after the first harvest of the SRC site) to 11 January 2014, corresponding to the second cycle of cultivation. The period of calculation of the GHG budget for the REF site went instead from 1 September 2011 until 31 August 2013. However, manual chamber measurements of $\mathrm{CH}_{4}$ and $\mathrm{N}_{2} \mathrm{O}$ at the REF site started at the beginning of April 2012. The 24 months considered for the SRC site corresponded to the second cycle of the short-rotation coppice and thus did not include the period right after the conversion of agricultural land. This rotation was supposed to terminate with the harvest. However, due to unfavourable climate conditions (a strong drought during summer), the harvest of the SRC site, planned for 2014, was postponed to 2015.

The SRC site had a planting density of around 5300 cuttings per hectare, which were planted in rows $2.5 \mathrm{~m}$ apart, with a distance of $0.75 \mathrm{~m}$ between plants in the same row. The first harvest occurred in January 2012. The SRC site was irrigated during the driest periods in summer using a system of tubes installed $35 \mathrm{~cm}$ belowground on alternate inter-rows, totalling about $210 \mathrm{~mm}$ in 2012 and $80 \mathrm{~mm}$ in 2013 of equivalent precipitation added to the soil. No fertilizer was provided to the SRC site in 2012 , while $40 \mathrm{~kg}$ of urea per hectare were dissolved in the irrigation water in a single event in 2013. Insecticide (DECIS) was used in May 2012 against Chrysomela populi L. At the REF site a shallow tillage $(15 \mathrm{~cm})$ was performed in September 2011 with a rotary harrow, and the mixture of clover and ryegrass was sown. At the end of April 2012 half of the crop was converted to sorghum (Sorghum vulgare Pers.) after a period of aridity in spring time. Both the clover and the sorghum were grazed during the growing season, with grazing removing all the above-ground biomass from the sorghum, while the clover was harvested at the end of the cycle. At the end of October 2012 the land was tilled at $40 \mathrm{~cm}$ depth, and winter wheat was sown in November. In April 2013 herbicide was distributed over the wheat (Buctril, at a rate of $1 \mathrm{Lha}^{-1}$ ), which was harvested at the beginning of July 2013 and no other operation was performed until the end of August. Sorghum was irrigated on several days in summer using a sprinkler with a total amount of $275 \mathrm{~mm}$ of equivalent precipitation, while no irrigation was applied to the winter wheat. Sorghum was also fertilized twice with $150 \mathrm{~kg} \mathrm{ha}^{-1}$ of ammonium nitrate, while $200 \mathrm{~kg} \mathrm{ha}^{-1}$ of the same fertilizer were provided once to the wheat. Apart from irrigation and fertigation, all the operations described above were performed using two different types of tractors, generating different diesel consumptions associated with each operation (Table 3 ).

An older SRC site (indicated hereafter as O_SRC site), located alongside the other one and subjected to the same type of management but planted in 2007, was used in the estimation of SOC content loss caused by the LUC. This was necessary as the expected SOC loss following the conversion (i.e. during the first rotation) was not measured.

In the 24 months considered for the GHG budget of the SRC site, precipitations totalled $1078 \mathrm{~mm}$, with an average temperature of $14.72^{\circ} \mathrm{C}$, while in the 24 months used for the REF site precipitations were $1157 \mathrm{~mm}$, with an average temperature of $15.31^{\circ} \mathrm{C}$. In both cases yearly values of pre- 


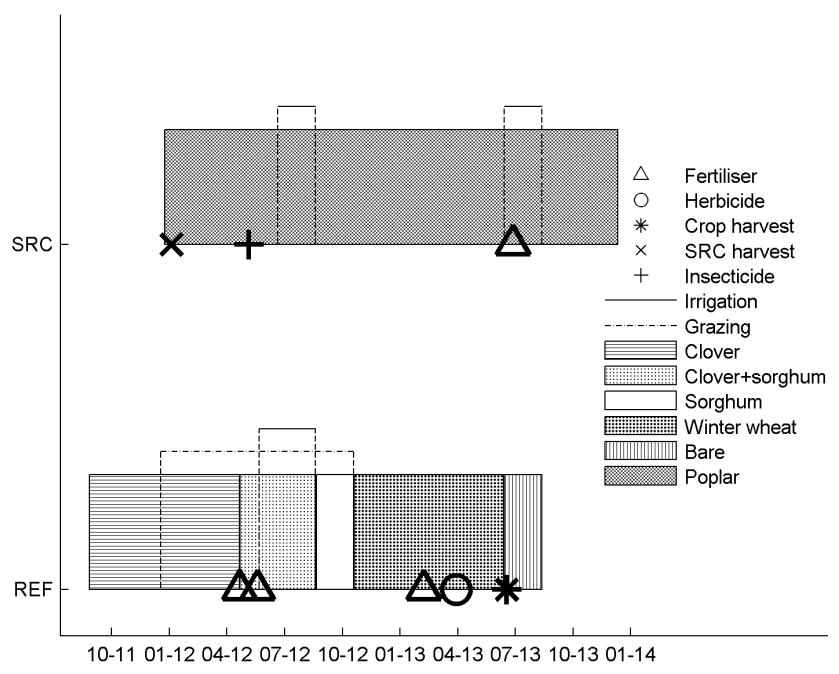

Figure 1. Scheme of the chronological land cover during the cultivation cycle taken into account for GHG budget calculation in the two ecosystems. The expected harvest of poplar at the beginning of 2014 was postponed of 1 year: for that reason data from the previous harvest (beginning 2012) were taken into account for GHG budget calculation. Textures indicate different land cover type, symbols mark the most important management practices, straight lines indicate the periods in which sites were irrigated, dashed line period of grazing. SRC: short-rotation coppice site; REF: reference site; in the $x$ axis dates are reported as month-year (mm-yy).

cipitation were lower than the long-term average of $766 \mathrm{~mm}$ (Blasi, 1993). An intense drought occurred in summer 2012, with no rain from the beginning of June until the end of August, in contrast to the long-term average of cumulate rainfall in these months (110 mm, Blasi, 1993). Soils were classified as Chromic Luvisol according to the World Reference Base classification (IUSS, 2014), with a clay-loam texture. Values of $\mathrm{pH}$ ranged between 5.88 at the REF site, 6.66 at the O_SRC site, and 6.69 at the SRC site. The stock of nitrogen (N) up to $70 \mathrm{~cm}$ was not significantly different between sites, ranging from $3.16 \pm 1.60$ to $3.19 \pm 1.47$ and $3.25 \pm 1.47 \mathrm{Mg}$ $\mathrm{Nha}^{-1}$ respectively for SRC, O_SRC, and REF sites. See Fig. 1 for a schematic representation of land cover and management events of the two sites.

\section{$2.3 \quad \mathrm{~F}_{\mathrm{CO}_{2}}$ : eddy covariance measurements}

The EC technique was used to determine the turbulent vertical fluxes of momentum, $\mathrm{CO}_{2}$, and latent and sensible heat. A 3-D sonic anemometer was installed at each site for highfrequency measurements of wind speed, wind direction, and sonic temperature. $\mathrm{CO}_{2}$ and water vapour densities were collected using a fast-response open-path infrared gas analyser (see Table 1 for models and manufacturers). These instruments were mounted on towers located approximately in the centre of the fields. At the REF site the mast was $3 \mathrm{~m}$ high, while an extendible telescopic pole was used at the SRC site in order to always measure turbulences above the roughness layer (Foken, 2008). Measurement heights ranged between 5 and $8 \mathrm{~m}$, and the distances of the measuring system over the $d+z_{0}$ plane ranged between 2 and $5 \mathrm{~m}(d$ : displacement height; $z_{0}$ : roughness length). Several meteorological variables above and belowground were continuously measured on a $30 \mathrm{~min}$ basis to properly calculate fluxes and characterize the two sites. In Table 1 the complete instrument set-up is described, including both meteorological and high-frequency variables.

Half-hourly fluxes were calculated with EddyPro ${ }^{\circledR}$ software (LI-COR, Lincoln, NE, USA). Several corrections to the time series (Aubinet et al., 2012) were applied as reported in Table 2. Post-processing included spike removal and friction velocity $\left(u_{*}\right)$ filtering (Papale et al., 2006), gap filling using the marginal distribution sampling (MDS) approach and the partitioning of $F_{\mathrm{CO}_{2}}$ into gross primary production (GPP) and ecosystem respiration $\left(R_{\text {eco }}\right)$ components (Reichstein et al., 2005). The gap-filled $F_{\mathrm{CO}_{2}}$ and its components were then cumulated along the 24-month period considered.

Uncertainty in $F_{\mathrm{CO}_{2}}$ was calculated on the basis of the uncertainty in the $u_{*}$ filtering, assuming that the main potential systematic error is due to advection and thus linked to the $u_{*}$ filtering. One hundred thresholds were calculated using a bootstrapping technique and then applied to filter the data. For each half-hour, the median of the distribution of $F_{\mathrm{CO}_{2}}$ obtained using the 100 thresholds was used for the GHG budget (Gielen et al., 2013), and the range of uncertainty was derived as half the range between the 16th and the 84th percentile.

\subsection{Soil characteristics and SOC stock and changes}

To better characterize the soil properties and to quantify the changes in SOC stocks due to the installation of the poplar plantation, a number of soil analyses were performed at the three sites in two different periods. In the first phase, in February 2012, three soil trenches $150 \mathrm{~cm}$ wide were opened randomly at each site and the soil sampled by depth $(0-5$, $5-15,13-30,30-50,50-70,70-100 \mathrm{~cm}$ ) at opposite sides of the profiles, resulting in six replicate samples per depth. The bottom layer $(70-100 \mathrm{~cm})$ was absent at the REF site due to the presence of bedrock at $80 \mathrm{~cm}$ rather than at $100 \mathrm{~cm}$ as at both the SRC sites. Samples were collected using a cylinder to also determine the bulk density. Main goals of this first sampling campaign were to describe the soil characteristics and to determine the number of replicates necessary to detect, with statistical significance, a change in SOC content of $0.5 \mathrm{~g}$ $\mathrm{C} \mathrm{kg}^{-1}$ soil (Conen et al., 2003). In the SRC and O_SRC sites 10 samples of the organic layer were also taken, removing all the material present over the mineral surface within a squared frame with an area of $361 \mathrm{~cm}^{2}$. At the REF site this sampling was not performed because a permanent organic layer was not present. All samples were air-dried at room temperature and then sieved at $2 \mathrm{~mm}$ to separate the coarse fraction, and the analyses were performed on the fine earth. The $\mathrm{pH}$ was 
Table 1. Instrumental set-up of the two towers. SRC: short-rotation coppice site; REF: reference site; $T_{\text {air }}$ air temperature; $T:$ temperature; RH: relative humidity; PAR: photosynthetically active radiation; $M_{\mathrm{SOIL}}$ : soil water content; $G$ : soil heat flux; $P$ : precipitation; EC: eddy covariance; prof: profile. Four-component radiometers were used to measure short- and long-wave radiations and to derive net radiation. SRC site soil profiles were located in irrigated and non-irrigated inter-rows. Precipitation and PAR were assumed to be consistent in the two ecosystems.

\begin{tabular}{lll}
\hline & SRC & REF \\
\hline$T_{\text {air }}$ and RH & MP-100, Rotronic AG, Bassersdorf, CH & MP-100, Rotronic AG, Bassersdorf, CH \\
PAR & Li-190, LI-COR, Lincoln, NE, USA & - \\
Radiations & CNR-1, Kipp \& Zonen, Delft, NL & NR01, Hukseflux, Delft, NL \\
$M_{\text {SOIL }}$ & CS616, Campbell Scientific, Logan, UT, USA (2 prof.) & CS616, Campbell Scientific, Logan, UT, USA (1 prof.) \\
Soil $T$ & 107, Campbell Scientific, Logan, UT, USA (2 prof.) & 107, Campbell Scientific, Logan, UT, USA (1 prof.) \\
$G$ & HFT3, REBS Inc., Seattle, WA, USA & HFP01, Hukseflux, Delft, NL \\
$P$ & - & ARG100, EML, North Shields, UK \\
Logger & CR3000, Campbell Scient., Logan, UT, USA & CR1000 Campbell Scient. Logan, UT, USA \\
Anemometer & CSAT3, Campbell Scientific, Logan, UT, USA & USA-1, Metek GmbH, Elmshorn, DE \\
Gas analyser & LI-7500, LI-COR, Lincoln, NE, USA & LI-7500A, LI-COR, Lincoln, NE, USA \\
\hline
\end{tabular}

Table 2. Correction steps applied to the time series using LICOR EddyPro software.

\begin{tabular}{ll}
\hline Correction & Reference \\
\hline Despiking & Vickers and Mahrt (1997) \\
$\begin{array}{l}\text { Density fluctuations } \\
\text { Maximization of covariance }\end{array}$ & Webb et al. (1980) \\
for time lag compensation & Aubinet et al. (2000) \\
Linear detrending for trend removal & \\
Two-dimensional coordinate rotation & Gash and Culf (1996) \\
High-pass filtering effect & Wilczak et al. (2001) \\
Low-pass filtering effect & Moncrieff et al. (1997) \\
\hline
\end{tabular}

measured potentiometrically in deionized water by using a sure-flow electrode and a ratio of soil to solution of $1: 2.5$ $(\mathrm{w}: \mathrm{w})$. The texture, on the other hand, was determined using the pipette method after the organic cements were removed by using sodium hypochlorite adjusted at $\mathrm{pH} 9$ (Mikutta et al. 2005). The sand fraction was separated by wet sieving at $53 \mu \mathrm{m}$, while the silt and the clay fractions were separated by time sedimentation according to the Stokes law. Total carbon (C) and nitrogen concentrations were measured on finely ground samples by dry combustion (ThermoFinnigan Flash EA112 CHN), while SOC and N stocks were determined taking into account soil $\mathrm{C}$ and $\mathrm{N}$ concentrations and a weighed mean of bulk density, depth of sampling, and stoniness (Boone et al., 1999). During the second phase in March 2014, a new sampling was performed at the REF, SRC, and O_SRC sites. The number of samples necessary to detect an SOC change statistically was 50 , as derived from the first phase. Samples were taken from the first $15 \mathrm{~cm}$ of soil, as most of the changes in a short period occur in the shallower layers. C concentration was measured and SOC stocks recalculated. The normality of the distributions was checked using a Chi-squared test (Pearson, 1900). An analysis of variance (ANOVA) test (Fisher, 1919), combined with a Tukey multi- ple comparison test, was used to check whether SOC stocks were different between the sites. As data of $\mathrm{F}_{\mathrm{CO}_{2}}$ from the beginning of the cultivation are missing, SOC changes due to the installation of the poplar cuttings were calculated building a linear regression between SOC content of the SRC site (4 years old) and the O_SRC site (7 years old) and then estimating the SOC at the time of plantation (year " 0 "). Following the "free-intercept model" described by AndersonTeixeira et al. (2009), the SOC content change due to the plantation of the SRC was then extrapolated considering the difference between the SOC content at year 0 and the one measured at the REF site, assuming the SOC content at the REF site to be in equilibrium, as this type of land use was constant in the last 30 years. Uncertainties in SOC concentration and stock were calculated as standard deviations from the mean values of each repeated measure, while errors were estimated using the law of error propagation as reported by Goodman (1960).

\subsection{Soil $\mathrm{CH}_{4}$ and $\mathrm{N}_{2} \mathrm{O}$ fluxes}

On-site measurements of $\mathrm{CH}_{4}$ and $\mathrm{N}_{2} \mathrm{O}$ soil fluxes were combined with laboratory incubation analyses, where soil samples were tested at different water contents and $\mathrm{N}$ addition levels. Field measurements of soil $\mathrm{N}_{2} \mathrm{O}$ and $\mathrm{CH}_{4}$ fluxes were carried out at the two sites using nine manual, dark, static PVC chambers $(15 \mathrm{~cm}$ diameter, $20 \mathrm{~cm}$ height, and total volume $0.0039 \mathrm{~m}^{3}$ ) per site, placed over as many PVC collars (7 $\mathrm{cm}$ height, $15 \mathrm{~cm}$ diameter) permanently inserted into the soil at $5 \mathrm{~cm}$ depth for the period of observation. At the SRC site, three collars were distributed along one of the lines of trees (by placing each of the collars between two trees), three along one of the irrigated inter-rows, and three along one of the non-irrigated inter-rows; all were placed at a distance of about $5 \mathrm{~m}$ from each other. At the REF site, collars were placed in three different blocks of three collars each. Gas 
samples were collected from each chamber at the closure time and 30 and $60 \mathrm{~min}$ after closure. Samples were stored in glass vials provided with a butyl rubber airtight septum $(20 \mathrm{~mL})$, and the concentration of $\mathrm{N}_{2} \mathrm{O}$ and $\mathrm{CH}_{4}$ was measured using a TRACE Ultra gas chromatograph (GC; Thermo Scientific, Rodano, IT). The flux detection limit due to the concentration measurement was of the order of about $0.1 \mathrm{mg}$ of $\mathrm{CH}_{4}$ or $\mathrm{N}_{2} \mathrm{O} \mathrm{m}^{-2}$ day $^{-1}$, and the analytical precision of the GC for standards at ambient concentration was approximately $3-5 \%$, using 1 standard deviation as a measure of mean error. Further details on GC are found in Castaldi et al. (2013). Measurements started 2 weeks after collar insertion and samples were collected every $2-4$ weeks, depending on land management practices and weather conditions, for a total of 30 dates at the SRC site and 24 at the REF site. Similar frequencies were used in previous studies (e.g. Pihlatie et al., 2007; Weslien et al., 2009) and were considered pertinent on the basis of the low magnitude of the measured fluxes. To test if fertilization could trigger a peak of $\mathrm{N}_{2} \mathrm{O}$ emission as found in previous studies (e.g. Gauder et al., 2012), measurements at both sites were carried out more frequently during fertilization events (on average every 2 days), starting from the day before the application of fertilizer and for 1 week. Measurements also covered different soil and meteorological conditions, including periods of drought and rewetting. Measured average daily soil $\mathrm{CH}_{4}$ and $\mathrm{N}_{2} \mathrm{O}$ fluxes were cumulated over the 24 months by linear interpolation as described by Marble et al. (2013), and uncertainty calculated propagating the standard deviations of the replicates. $F_{\mathrm{N}_{2} \mathrm{O}}$ and $F_{\mathrm{CH}_{4}}$ were converted to $\mathrm{CO}_{2}$ equivalents by multiplication by 298 and 25 respectively. These factors were based on the Intergovernmental Panel on Climate Change (IPCC) 100year global warming potential (GWP) weighted estimates of GHGs (Forster et al., 2007).

\subsubsection{Laboratory incubations}

Due to the fact that we do not have continuous measurements of non- $\mathrm{CO}_{2}$ fluxes from soil, we performed a laboratory analysis to verify the accuracy of field campaigns. Laboratory incubations were carried out to assess the GHG emission rates under controlled laboratory conditions in soil treated with both water and nitrogen addition and to quantify the rates of soil mineralization and nitrification. The purpose of the incubation was to assess whether the fluxes were driven by limiting conditions such as water and/or nitrogen or a slow rate of organic $\mathrm{N}$ mineralization, as found in a Mediterranean coppice site in the same region (Castaldi et al., 2009; Gundersen et al., 2012). The addition of $\mathrm{N}$ allowed us to check whether short-time peaks of emissions occurred that could escape due to the selected frequency of sampling. Soil cores (7 cm diameter, $10 \mathrm{~cm}$ height) sampled in the two ecosystems were incubated at $20^{\circ} \mathrm{C}$. Water was then added to reach three different ranges of water-filled pore space (WFPS): 20 (i.e. the value estimated at sampling), 50, and $90 \%$, each of them replicated five times. The sample with the highest WFPS percentage was also replicated with or without nitrogen supply $\left(100 \mathrm{~kg} \mathrm{~N} \mathrm{ha}^{-1}\right.$ of $\left.\mathrm{NH}_{4} \mathrm{NO}_{3}\right)$. Cores were placed in gas-tight $1 \mathrm{~L}$ jars, and $6 \mathrm{~mL}$ air samples were collected immediately after closure and after $3 \mathrm{~h}$ of incubation for $\mathrm{N}_{2} \mathrm{O}$ production determination. Gas concentration was determined by gas chromatography on the day after the treatment and in the following 5 days, leaving the jars open during this period and closing them only when $\mathrm{N}_{2} \mathrm{O}$ production needed to be determined, in order to avoid the development of liquid oxygen tension conditions. Net mineralization and nitrification and the net potential nitrification rate were determined on sieved ( $2 \mathrm{~mm}$ mesh) soil samples over 14 days of incubation, while for the determination of potential nitrification, soil was amended with ammonium sulfate $\left(\mathrm{NH}_{4}\right)_{2} \mathrm{SO}_{4}\left(100 \mu \mathrm{g} \mathrm{N} \mathrm{g}{ }^{-1}\right.$ dry soil). A modified method (Kandeler, 1996; Castaldi and Aragosa, 2002) was used to extract $\mathrm{NH}_{4}^{+}$and $\mathrm{NO}_{3}^{-}$from the soil at $T_{0}$ and $T_{14}$ days for further concentration determination with calibrated specific electrodes after the addition of a $\mathrm{pH}$ and ionic buffer $0.4 \mathrm{~mL}$ of ISA (Ionic Strength Adjustor; Orion cat. no. 951211 and Orion cat no. 930711). Mineralization rates were calculated as the total soil mineral $\mathrm{N}(\mu \mathrm{g}$ of $\mathrm{N}-\mathrm{NH}_{4}{ }^{+}+\mathrm{N}^{-\mathrm{NO}_{3}}{ }^{-}$per gram of dry soil) measured after 14 days of incubation $\left(T_{14}\right)$ minus total mineral $\mathrm{N}$ measured at the incubation start $\left(T_{0}\right)$ divided by the number of days of incubation. Nitrification rates were calculated similarly, considering only the amount of ${\mathrm{N}-N O 3^{-}}^{-}$produced at $T_{14}$ minus the amount of ${\mathrm{N}-\mathrm{NO}^{-}}^{-}$present at $T_{0}$.

In order to compare results obtained with soil cores to field conditions, in situ WFPS percentage was calculated for the whole period of field monitoring:

$\mathrm{WFPS} \%=\frac{M_{\mathrm{SOIL}}}{1-\rho_{\mathrm{BULK}} / \rho_{\mathrm{PART}}} \times 100$,

where $M_{\text {SOIL }}$ is the volumetric soil moisture $\left(\mathrm{m}^{3} \mathrm{~m}^{-3}\right)$, $\rho_{\text {BULK }}$ is the bulk density $\left(\mathrm{Mg} \mathrm{m}^{-3}\right)$, and $\rho_{\text {PART }}$ is the particle density $\left(\mathrm{Mg} \mathrm{m}^{-3}\right)$. For mineral soil, $\rho_{\text {PART }}$ is approximated to that of common silicate materials $\left(2.65 \mathrm{Mg} \mathrm{m}^{-3}\right.$; Chesworth, 2008).

\subsection{Emissions due to management}

Life cycle inventory (LCI) was used to estimate the anthropogenic GHG emissions due to farming operations (Robertson et al., 2000) at both sites (Table 3) and the GHG emissions due to grazing at the REF site (Table 4). The present study is not a full LCA, but the LCA approach was used to estimate emissions caused by field management as described in the following. In particular, indirect land use change (iLUC) was not taken into account. iLUC includes modifications in land use elsewhere in the world triggered by the local substitution of arable land with an energy crop (Djomo et al., 2013). iLUC occurred outside the boundary of the system we used for this analysis, i.e. the farm. Fossil fuel emissions associated with the cultivation of the SRC and REF sites 
included on-site emissions from tractors (used to carry out all the main operations: ploughing, seeding, solid fertilization, harvesting) and irrigation, as well as off-site emissions from the production and transport of agricultural inputs (fertilizer, insecticide, herbicide). Emissions due to the production of tractors were considered negligible, as in Budsberg et al. (2012) and Caputo et al. (2014). On-site GHG emissions due to diesel consumption were calculated as the product of the amount of fuel diesel consumed to carry out a given farm activity (e.g. harvesting) and the emissions factor of diesel, $90 \mathrm{~g} \mathrm{CO}_{2} \mathrm{eq} \mathrm{MJ}^{-1}$ (Table 3). This factor includes emission costs due to the combustion of diesel $\left(74 \mathrm{~g} \mathrm{CO}_{2} \mathrm{eq} \mathrm{MJ}^{-1}\right)$ and emissions due to its production and transportation (16 g $\mathrm{CO}_{2}$ eq $\mathrm{MJ}^{-1}$; Edwards et al., 2007). Considering the energy density of diesel to be $38.6 \mathrm{MJ} \mathrm{L}^{-1}$ (Alternative Fuels Data Center, 2014), producing, transporting, and burning $1 \mathrm{~L}$ of diesel emitted $3474 \mathrm{~g} \mathrm{CO}_{2}$ eq. An exception was made for harvesting at the SRC site, for which emissions for diesel consumption relative to the previous harvest (2012) were considered, as the harvest at the end of the cycle was postponed. Emissions due to irrigation were calculated by multiplying the electricity consumed in powering the pumps by an emissions factor of $750 \mathrm{~g} \mathrm{CO}_{2} \mathrm{kWh}^{-1}$, calculated as the average of different emission factors for different sources of electricity (Bechis and Marangon, 2011) weighted according to the Italian electricity grid mix, derived from the Italian energetic balance 2012 (Italian Ministry of Interior, 2013). Off-site emission costs for fertilizers and insecticides were estimated as the product of the amount of fertilizer or insecticide applied and the emission factors for manufacturing $1 \mathrm{~kg}$ of fertilizer or insecticide: $4018.9 \mathrm{~g} \mathrm{CO}_{2} \mathrm{~kg}^{-1} \mathrm{~N}$ for urea (NPK rating 40-0-0), $4812 \mathrm{~g} \mathrm{CO}_{2} \mathrm{~kg}^{-1} \mathrm{~N}$ for diammonium phosphate (NPK 18-46-0) ${ }^{1}, 7030.8 \mathrm{~g} \mathrm{CO}_{2} \mathrm{~kg}^{-1} \mathrm{~N}$ for ammonium nitrate (NPK 33-0-0), and 7481.9 $\mathrm{g} \mathrm{CO}_{2} \mathrm{~kg}^{-1} \mathrm{~N}$ for calcium ammonium nitrate (NPK 27-0-0; Wood and Cowie, 2004). Although emission factors differ among insecticide types, in this analysis we assumed that the difference is negligible as the use of insecticides was limited, and thus considered the emission factor of insecticide (active ingredient: deltamethrin) as the product of energy required to produce $1 \mathrm{~kg}$ of insecticide $\left(310 \mathrm{MJ} \mathrm{kg}^{-1}\right)$ and the emission rate of insecticide (60 $\mathrm{g} \mathrm{CO}_{2} \mathrm{MJ}^{-1}$; Barber, 2004; Liu et al., 2010). The emission factor of herbicide was taken from the literature (Ceschia et al., 2010): $3.92 \mathrm{~kg} \mathrm{C}$ per $\mathrm{kg}$ of product. The fuel used for the application of chemical products was included in the on-site calculations described above. All the contributions listed above were converted on a surface basis (Table 3).

\footnotetext{
${ }^{1}$ This includes production and transport costs of the overall fertilizer, including $\mathrm{P}$.
}

\subsection{Biomass use and GHG offset}

During the first year of cultivation, the REF site was grazed by sheep, which were brought to the field in defined periods (Table 4). Hence, at different periods, the above-ground biomass (AGB) from the REF site was either grazed by sheep, provided as hay to other livestock, destined for meat and milk production, or in the case of wheat used in food (grains) and feed (foliage) production. Due to the different species cultivated throughout the 2 years and to the different uses of the biomass, $F_{\mathrm{EXP}}$ of the REF site (Eq. 2) includes the following:

$F_{\mathrm{EXP}}=E_{\mathrm{CH}_{4}, \text { on }}+E_{\mathrm{CO}_{2} \text {, on }}+E_{\mathrm{CH}_{4}, \text { off }}+E_{\mathrm{CO}_{2}, \text { off }}$,

where the first subscript indicates whether the exported $\mathrm{C}$ is re-emitted to the atmosphere as $\mathrm{CO}_{2}$ or $\mathrm{CH}_{4}$ and the second subscript distinguishes between emissions occurring onsite (on) and off-site (off). In fact, the percentage of AGB ingested by herbivores on grassland varies with the intensity of management (Soussana et al., 2010). In the present study, however, what was left in the field by the sheep was then harvested and provided to them off-site. We assumed then that, apart from the grains in wheat ears, all the AGB was ingested by sheep or other livestock and that the digestible portion of the organic $\mathrm{C}$ ingested was respired back to the atmosphere as $\mathrm{CO}_{2}$ or emitted as $\mathrm{CH}_{4}$ via enteric fermentation (Eq. 4; Soussana et al., 2007). Biomass at the REF site was sampled every $2-3$ weeks in five plots $(0.5 \mathrm{~m} \times 0.5 \mathrm{~m})$ randomly selected within the field. At three dates, samples were collected immediately after grazing in a grazed area and in an undisturbed area to quantify the intensity of mowing $(68 \%)$ and identify the $\mathrm{C}$ ingested on-site and off-site. Biomass samples were oven-dried at $70^{\circ} \mathrm{C}$ to constant mass and weighed. Total AGB was obtained by cumulating dry weights measured immediately before each grazing event, each time subtracting the $32 \%$ of the dry weight of the previous sample to consider mowing intensity. The IPCC methodology (Dong et al., 2006) was then used to estimate $E_{\mathrm{CH}_{4} \text {,on }}$ (Eq. 4), adjusting the methane emission factor per animal considering the average weight $(55 \mathrm{~kg})$ of sheep $\left(19 \mathrm{~g} \mathrm{CH}_{4}\right.$ head $\left.^{-1} \mathrm{day}^{-1}\right)$ and multiplying it by the daily number of sheep present on-site. The method in Soussana et al. (2007; their Eq. 4) was then adapted to estimate the other three components in Eq. (4): $E_{\mathrm{CH}_{4} \text {,off }}$ was estimated by applying to the C ingested off-site the ratio between the $\mathrm{C}$ weight in $E_{\mathrm{CH}_{4} \text {,on }}$ and the $\mathrm{C}$ ingested on-site. The $\mathrm{C}$ emitted as $\mathrm{CH}_{4}$ was subtracted from the digestible portion of the $\mathrm{C}$ ingested, assumed to be $65 \%$, and the remaining converted in $\mathrm{CO}_{2}$ so as to estimate $E_{\mathrm{CO}_{2} \text {, on }}$

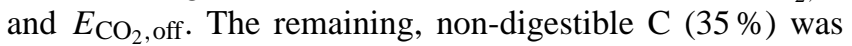
assumed to be returned to the SOC of the grassland (for the on-site part) or of other systems (for the off-site part) as faeces, thus not contributing to the GHG balance. The portion that formed the $\mathrm{C}$ stock in the body mass of animals was considered negligible (Soussana et al., 2007). For the sake of simplicity, we assumed that the $\mathrm{C}$ content of wheat ears will 
Table 3. Farming activities. Three tractors of different power were normally used to collect chips: two of type 1 and one of type 2. DAP: diammonium phosphate; AN: ammonium nitrate; CAN: calcium ammonium nitrate. SRC and REF as defined previously. Reported units are given per hectare and activity. Occurrences of the same type of operation with different characteristics are listed in the same cell using lowercase letters.

\begin{tabular}{|c|c|c|c|}
\hline Operation & $\begin{array}{l}\text { Fuel consumption } \\
\text { (unit } \mathrm{ha}^{-1} \text { ) }\end{array}$ & $\begin{array}{l}\text { Input rates } \\
\text { (unit ha }{ }^{-1} \text { ) }\end{array}$ & Site \\
\hline Harvesting - wood chipper & $30 \mathrm{~L}$ diesel & - & SRC \\
\hline Harvesting - tractor type 1 & $20 \mathrm{~L}$ diesel & - & $\mathrm{SRC}$ \\
\hline Harvesting - tractor type 2 & $10 \mathrm{~L}$ diesel & - & SRC \\
\hline Shallow tillage & $8 \mathrm{~L}$ diesel & - & SRC, REF \\
\hline Application of insecticide & $1.125 \mathrm{~L} \mathrm{diesel}$ & $1.25 \mathrm{~kg} \mathrm{DECIS}^{\circledR}$ & SRC \\
\hline Mechanical weeding & $4 \mathrm{~L}$ diesel & - & SRC \\
\hline Ploughing & $8 \mathrm{~L}$ diesel & - & SRC, REF \\
\hline Sowing & $2 \mathrm{~L}$ diesel & - & REF \\
\hline Seed covering & $4 \mathrm{~L}$ diesel & $\begin{array}{l}\text { - } \\
\text { a. } 150 \mathrm{~kg} \text { DAP }\end{array}$ & $\begin{array}{l}\text { REF } \\
\text { a. REF }\end{array}$ \\
\hline $\begin{array}{l}\text { Application } \\
\text { of fertilizer }\end{array}$ & $2 \mathrm{~L}$ diesel & $\begin{array}{l}\text { b. } 150 \mathrm{~kg} \mathrm{AN} \\
\text { c. } 200 \mathrm{~kg} \text { CAN } \\
\text { d. } 40 \mathrm{~kg} \text { Urea }\end{array}$ & $\begin{array}{l}\text { b. REF } \\
\text { c. REF } \\
\text { d. SRC }\end{array}$ \\
\hline Reaping & $20 \mathrm{~L}$ diesel & - & REF \\
\hline Chemical weeding & $1.125 \mathrm{~L} \mathrm{diesel}$ & 1 L Buctril $^{\circledR}$ & $\mathrm{REF}$ \\
\hline Bale & 7.5 L diesel & - & $\mathrm{REF}$ \\
\hline Irrigation & $\begin{array}{l}\text { a. } 471 \mathrm{kWh} \text { electricity } \\
\text { b. } 149 \mathrm{kWh} \text { electricity }\end{array}$ & $\begin{array}{l}\text { a. } 16 \mathrm{~L} \mathrm{H}_{2} \mathrm{O} \\
\text { b. } 46 \mathrm{~L} \mathrm{H}_{2} \mathrm{O}\end{array}$ & $\begin{array}{l}\text { a. SRC } \\
\text { b. REF }\end{array}$ \\
\hline
\end{tabular}

Table 4. Grazing calendar and methane emissions at the REF site. Graz_days: number of days with grazing; num: number of sheep in the cropland.

\begin{tabular}{lrr}
\hline Months & Graz_days & Num (per 9 ha) \\
\hline December 2011 & 10 & 800 \\
January 2012 & 7 & 400 \\
June 2012 & 2 & 580 \\
August 2012 & 1 & 580 \\
September 2012 & 2 & 580 \\
October 2012 & 5 & 400 \\
\hline
\end{tabular}

also be respired back to the atmosphere as $\mathrm{CO}_{2}$ quickly, and it was thus included in $E_{\mathrm{CO}_{2} \text {,off }}$ (Eq. 4).

At the end of the cycle, poplar above-ground woody biomass (AGWB) of the SRC site was supposed to be harvested and burnt, thus, on the one hand, releasing $\mathrm{C}$ back to the atmosphere and, on the other, offsetting GHG emissions for fossil fuel displacement. To estimate poplar AGWB, stem diameters were measured at the end of the cycle after the leaves had fallen. Three rows of trees were selected inside the plantation and the diameters of these trees were measured (minimum threshold $0.5 \mathrm{~cm}$ ) at $1 \mathrm{~m}$ height. A simple model considering the regression between individual shoot dry weight $\left(W_{\mathrm{D}}\right)$ and $1 \mathrm{~m}$ diameter $(D)$ was used:

$W_{\mathrm{D}}=b \times D^{c}$, where $b$ and $c$ are empirical parameters, $W_{\mathrm{D}}$ is given in kilograms of dry mass, and $D$ is given in centimetres. Parameters were set as $b=0.0847$ and $c=2.112$ following Mareschi (2008; see also Paris et al., 2011) for the second rotation cycle of clone AF2 of the plantation located in Bigarello (Mantua province). Among the plantations presented in this publication, Bigarello is the one with climatic and soil characteristics that are more similar and it also has the same root and shoot age. Dry combustion (1108EA, Carlo Erba, Milan, IT) was used to determine the $\mathrm{C}$ concentration for both sites. Regarding the GHG emissions offset, it was assumed that heat produced from SRC biomass will substitute heat produced from natural gas. The GHG offset $\left(F_{\mathrm{SAV}}\right)$ was estimated based on the yield of the SRC site, the energy density of poplar, the conversion efficiency of a typical biomass boiler in Italy, and the emission rate of heat production from natural gas in Italy:

$F_{\mathrm{SAV}}=Y \times H_{\mathrm{L}} \times \eta_{\mathrm{CONV}} \times I_{\mathrm{NG}}$,

where $Y$ is the biomass yield $\left(\mathrm{kg} \mathrm{m}^{-2}\right), H_{\mathrm{L}}$ is the low heating value of poplar $\left(13 \mathrm{MJ} \mathrm{kg}^{-1}\right.$ at $30 \%$ moisture content; Boundy et al., 2011), $\eta_{\mathrm{CONV}}$ is the efficiency of conversion of poplar chips to heat, assumed in this study to be $84 \%$ (Saidur et al., 2011), and $I_{\mathrm{NG}}$ is the carbon emission rate (intensity) of heat produced from natural gas (i.e. $55.862 \mathrm{~g}$ $\mathrm{CO}_{2} \mathrm{eq} \mathrm{MJ}^{-1}$ ) for Italy (Romano et al., 2014). 


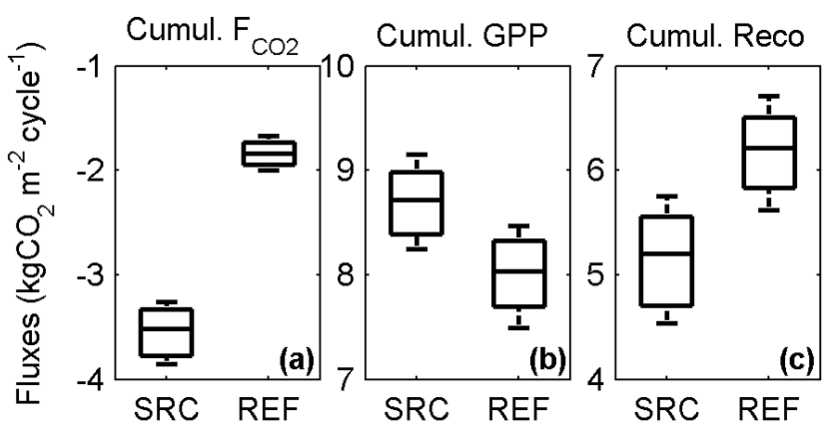

Figure 2. Boxplot of the 24-month cumulative fluxes of net ecosystem exchange of $\mathrm{CO}_{2}\left(F_{\mathrm{CO}_{2}}, \mathbf{a}\right)$, gross primary production (GPP; b), and ecosystem respiration (Reco; c) from eddy covariance (EC) data at the REF and SRC sites. Each box represents the range 16th84th percentile: the central mark is the median, while the whiskers extend to the 5th and 95th percentiles.

\section{Results}

\subsection{Biogenic fluxes of $\mathrm{CO}_{2}$}

The cumulative $F_{\mathrm{CO}_{2}}$ at the REF site for the 2 years considered was $-1838 \pm 107 \mathrm{~g} \mathrm{CO}_{2} \mathrm{~m}^{-2}$, partitioned into $8032 \pm 313 \mathrm{~g} \mathrm{CO}_{2} \mathrm{~m}^{-2}$ absorbed through photosynthesis (GPP) and $6216 \pm 338 \mathrm{~g} \mathrm{CO}_{2} \mathrm{~m}^{-2}$ emitted by total $R_{\text {eco }}$. At the SRC site, cumulative $F_{\mathrm{CO}_{2}}$ was $-3512 \pm 224 \mathrm{~g}$ $\mathrm{CO}_{2} \mathrm{~m}^{-2}$, with a GPP equal to $8717 \pm 298$ and $R_{\text {eco }}$ equal to $5205 \pm 425 \mathrm{~g} \mathrm{CO}_{2} \mathrm{~m}^{-2}$ (Fig. 2). Hence, the SRC site was a larger $\mathrm{CO}_{2}$ sink compared to the REF site over the measuring period, due to both the higher GPP and the lower ecosystem respiration of the SRC site relative to the REF site.

Seasonal differences between the sites in the net flux of $\mathrm{CO}_{2}$ were observed (Fig. 3). The main difference was the timing of the peak of $\mathrm{CO}_{2}$ uptake, which occurred during spring at the REF site and in summer at the SRC site. At both sites, peaks in $\mathrm{CO}_{2}$ uptake were higher in 2013 than in 2012. In the latter year, however, a minor peak of uptake was observed in early fall in the SRC site. Periods with positive net fluxes of $\mathrm{CO}_{2}$ appeared longer and with higher values at the REF site (Fig. 3, top). Air temperatures $\left(T_{\text {air }}\right)$ registered at the two sites were similar but higher in summer 2012, while the SWC (soil water content) at $30 \mathrm{~cm}$ depth was higher at the REF than at the SRC site (Fig. 3, bottom).

\subsection{Soil $\mathrm{CH}_{4}$ and $\mathrm{N}_{2} \mathrm{O}$ fluxes}

Daily average of both $F_{\mathrm{N}_{2} \mathrm{O}}$ and $F_{\mathrm{CH}_{4}}$ were very low in almost every measurement (Fig. 4), leading to low total cumulative soil $F_{\mathrm{N}_{2} \mathrm{O}}$ and $F_{\mathrm{CH}_{4}}$ for both the sites: overall soil non$\mathrm{CO}_{2}$ fluxes were $15.5 \pm 4.7 \mathrm{~g} \mathrm{CO}_{2} \mathrm{eq} \mathrm{m}^{-2}$ in 2 years for the SRC site and $0.5 \pm 1.6 \mathrm{~g} \mathrm{CO}_{2} \mathrm{eq} \mathrm{m}^{-2}$ in 2 years for the REF site. Both sites were small sources of $\mathrm{N}_{2} \mathrm{O}$ and small sinks of $\mathrm{CH}_{4}$. The $\mathrm{CH}_{4}$ sink at the SRC site was not significantly different from the one at the REF site, although on average

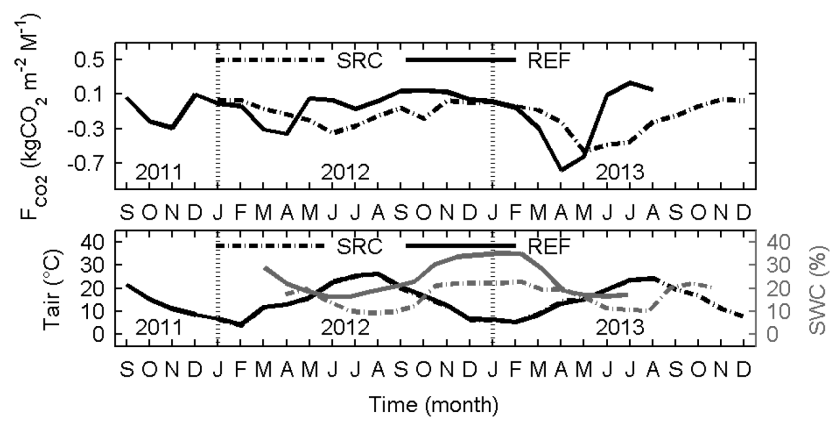

Figure 3. Monthly averages of $F_{\mathrm{CO}_{2}}$ at the REF and SRC sites (top panel). The bottom panel shows monthly averages of air temperature $\left(T_{\text {air }}\right)$ and soil water content $(\mathrm{SWC})$ at $30 \mathrm{~cm}$ depth. In both subplots dotted lines are used for the SRC site and continuous lines for the REF site, while in the bottom panel SWC is in grey and the $T_{\text {air }}$ in black.

slightly higher, and significantly higher $\mathrm{N}_{2} \mathrm{O}$ emissions were observed at the SRC site, although they were still very low. Measurements carried out during fertilization events showed no significant increase in the emission rates of $\mathrm{N}_{2} \mathrm{O}$ compared to non-fertilization periods: fluxes at the SRC site during the single instance of fertilization that occurred in the 2 years of study remained low, and at the REF site none of the four measurements taken during the fertilization event of June 2012 exceeded the detection limit of the GC.

\subsubsection{Laboratory incubations}

The $\mathrm{N}_{2} \mathrm{O}$ emissions determined in laboratory incubations confirmed that for most of the analysed WFPS percentage values, both soils were producing little $\mathrm{N}_{2} \mathrm{O}$ without $\mathrm{N}$ addition, even at a WFPS percentage normally considered to trigger $\mathrm{N}_{2} \mathrm{O}$ emission (WFPS: 60-80\%; Fig. 5). Addition of $\mathrm{N}$ did not seem sufficient to stimulate $\mathrm{N}_{2} \mathrm{O}$ production. In contrast, a very high WFPS percentage, close to saturation, was able to trigger a strong increase in $\mathrm{N}_{2} \mathrm{O}$ production in the soil of the REF site. Comparing the data reported in Fig. 5 with the field data of WFPS percentage for the REF site (Fig. 6), it can be seen that, most of the time, WFPS percentage was significantly below $70 \%$ in the whole profile and that at $5 \mathrm{~cm}$, where most of the interaction with added fertilizer might have occurred, the WFPS never exceeded $50 \%$. Mineralization and nitrification rates were quite low at both sites, with slightly positive mineralization rates at the SRC site $\left(0.28 \pm 0.05 \mu \mathrm{g} \mathrm{N} \mathrm{g}^{-1} \mathrm{~d}^{-1}\right)$ and a very small net immobilization in the REF samples $\left(-0.2 \pm 0.2 \mu \mathrm{g} \mathrm{N} \mathrm{g}^{-1} \mathrm{~d}^{-1}\right)$. Net nitrification rates calculated in the control (no $\mathrm{N}$ addition) were also quite low and varied between $0.5 \pm 0.05$ and $-0.1 \pm 0.2 \mu \mathrm{g} \mathrm{N} \mathrm{g}^{-1} \mathrm{~d}^{-1}$ at the REF site, which might suggest either quite a slow ammonification phase as a limiting step of the nitrification or a slow nitrification rate. However, when ammonium sulfate was added to soil samples, the potential nitrification rates significantly increased, reach- 

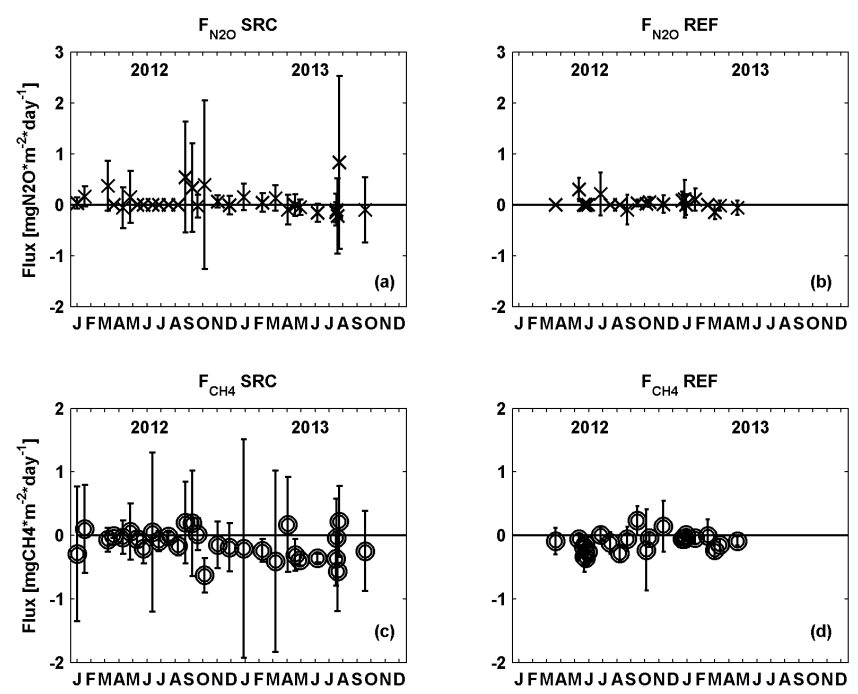

Figure 4. Fluxes of soil $\mathrm{N}_{2} \mathrm{O}$ (crosses) and $\mathrm{CH}_{4}$ (circles) at the $\mathrm{SRC}$ (a-c) and the REF (b-d) sites. Each marker represents the average of the nine chambers, with bars indicating their standard deviation. First letter of month on the $x$ axis.

ing $1.8 \pm 0.1 \mu \mathrm{g} \mathrm{Ng}^{-1} \mathrm{~d}^{-1}$ and $1.4 \pm 0.3 \mu \mathrm{g} \mathrm{Ng}^{-1} \mathrm{~d}^{-1}$ at the SRC and the REF sites respectively and suggesting that mineralization might be the limiting step of subsequent nitrification and denitrification processes in the field.

\subsection{Emissions due to management}

The GHG emissions due to management practices were, in total, $100.9 \pm 20 \mathrm{~g} \mathrm{CO}_{2} \mathrm{eq} \mathrm{m}^{-2}$ for the SRC site and $135.7 \pm 27.1 \mathrm{~g} \mathrm{CO}_{2} \mathrm{eq} \mathrm{m}^{-2}$ for the REF site. Analysing the individual contributions, differences arose between the two sites (Fig. 7): among the field operations, fertilization was the main source of GHG emissions at the REF site and one of the less important sources at the SRC site. Irrigation constituted a big portion of the GHG emissions from management operations at the SRC site, while at the REF site, despite similar amounts of water provided, irrigation played a smaller role, similar to harvesting and tillage. Emissions due to the latter were more relevant at the REF site than at the SRC site.

\subsection{SOC content changes}

In the first $15 \mathrm{~cm}$ of soil, total $\mathrm{C}$ stocks were $1603 \pm 376 \mathrm{~g}$ $\mathrm{C} \mathrm{m}^{-2}$ at the REF site, $1169 \pm 442 \mathrm{~g} \mathrm{C} \mathrm{m}^{-2}$ at the SRC site, and $1403 \pm 279 \mathrm{~g} \mathrm{C} \mathrm{m}^{-2}$ at the O_SRC site. The statistical analysis performed on the SOC stocks showed that there were statistically significant differences between the SOC data of the three sites (Table 5; $p$ value $=2.05 \times 10^{-7}$ ). The linear regression between the SOC content of SRC and O_SRC sites led to the relation

$\operatorname{SOC}(t)=78 \times t+857$
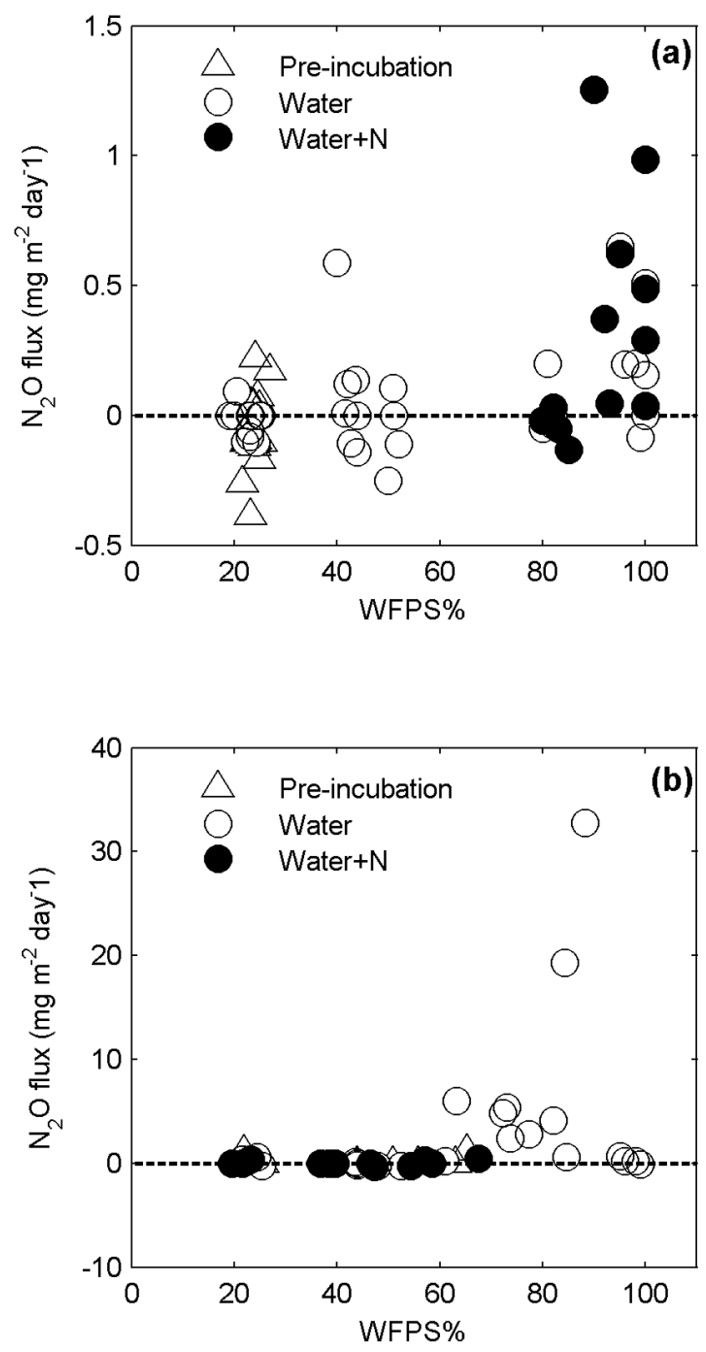

Figure 5. $\mathrm{N}_{2} \mathrm{O}$ fluxes from incubation experiment reported as a function of the water-filled pore space estimated for each individual replicate. In (a) data from samples taken at the SRC site are shown; in (b) data from REF site samples are shown.

where $t$ is the years from plantation and SOC is the soil organic carbon content expressed in grams of $\mathrm{C}$ per square metre. Estimated uncertainty was $25 \mathrm{~g} \mathrm{C} \mathrm{m}^{-2}$ for the slope value, and $139 \mathrm{~g} \mathrm{C} \mathrm{m}^{-2}$ for the intercept (Fig. 8), meaning that the yearly SOC accumulation after poplar plantation was $78 \pm 25 \mathrm{~g} \mathrm{C} \mathrm{m}^{-2}$ and the initial value $(t=0)$ was $857 \pm 139 \mathrm{~g}$ $\mathrm{C} \mathrm{m}^{-2}, 746 \pm 858 \mathrm{~g} \mathrm{C} \mathrm{m}^{-2}$ lower than the REF value and corresponding to the SOC content loss due to the installation of the SRC. As this loss was a positive flux occurring only once in a LUC at the installation of the cuttings (Arevalo et al., 2011) and as the expected lifespan of the SRC site was 12 years, the value considered for the 24-month GHG budget was $1 / 6$, corresponding to $124 \pm 143 \mathrm{~g} \mathrm{C} \mathrm{m}^{-2}(455 \pm 524 \mathrm{~g}$ $\left.\mathrm{CO}_{2} \mathrm{~m}^{-2}\right)$. 
Table 5. Soil characteristics of the layer $0-15 \mathrm{~cm}$. SRC and REF as previously defined; SOC: soil organic carbon; $\rho_{\mathrm{BULK}}$ : bulk density.

\begin{tabular}{|c|c|c|}
\hline Site & Variable & Value \pm SD \\
\hline \multirow{3}{*}{ 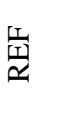 } & $\mathrm{C}(\%)$ & $1.46 \pm 0.34$ \\
\hline & $\rho_{\text {BULK }}\left(\mathrm{Mg} \mathrm{m}^{-3}\right)$ & $1.00 \pm 0.11$ \\
\hline & $\operatorname{SOC}\left(\mathrm{Mg} \mathrm{C} \mathrm{ha}^{-1}\right)$ & $16.03 \pm 3.76^{\mathrm{a}}$ \\
\hline \multirow{3}{*}{$\begin{array}{l}U \\
\frac{\sim}{\sim}\end{array}$} & $\mathrm{C}(\%)$ & $1.05 \pm 0.40$ \\
\hline & $\rho_{\text {BULK }}\left(\mathrm{Mg} \mathrm{m}^{-3}\right)$ & $1.12 \pm 0.15$ \\
\hline & $\operatorname{SOC}\left(\mathrm{Mg} \mathrm{C} \mathrm{ha}{ }^{-1}\right)$ & $11.69 \pm 4.42^{b}$ \\
\hline \multirow{3}{*}{\begin{tabular}{l}
0 \\
\multirow{2}{*}{} \\
| \\
0
\end{tabular}} & $\mathrm{C}(\%)$ & $1.38 \pm 0.27$ \\
\hline & $\rho_{\text {BULK }}\left(\mathrm{Mg} \mathrm{m}^{-3}\right)$ & $1.02 \pm 0.11$ \\
\hline & $\mathrm{SOC}\left(\mathrm{MgCha}^{-1}\right)$ & $14.03 \pm 2.79^{\mathrm{c}}$ \\
\hline
\end{tabular}

${ }^{\mathrm{a}-\mathrm{c}}$ Indicate statistically significant differences between the means of SOC.

\subsection{Biomass use and GHG offset}

The dry weight of AGB at the REF site totalled $0.72 \pm 0.18 \mathrm{~kg} \mathrm{~m}^{-2}$ for the grassland, of which $0.35 \pm 0.07 \mathrm{~kg} \mathrm{~m}^{-2}$ was due to the mix of clover and ryegrass and $0.37 \pm 0.17 \mathrm{~kg} \mathrm{~m}^{-2}$ came from the sorghum; winter wheat totalled $0.63 \pm 0.09 \mathrm{~kg} \mathrm{~m}^{-2}$, of which $0.36 \pm 0.05 \mathrm{~kg} \mathrm{~m}^{-2}$ was in the ears. The $\mathrm{C}$ content measured was $46 \%$ for all species, leading to a total of $621.0 \pm 93.2 \mathrm{~g}$ $\mathrm{C} \mathrm{m}^{-2}$ in $\mathrm{AGB}$, of which $265.5 \pm 79.2 \mathrm{~g} \mathrm{C} \mathrm{m}^{-2}$ was ingested by sheep on-site, $191.2 \pm 49.8 \mathrm{~g} \mathrm{C} \mathrm{m}^{-2}$ was used by livestock off-site, and $163.9 \pm 21.9 \mathrm{~g} \mathrm{C} \mathrm{m}^{-2}$ was converted to food. The estimated emissions of $\mathrm{CH}_{4}$ due to enteric fermentation totalled $4.3 \pm 1.3 \mathrm{~g} \mathrm{CH}_{4} \mathrm{~m}^{-2}$, equal to $3.3 \pm 1.0 \mathrm{~g} \mathrm{C} \mathrm{m}^{-2}$ emitted as $\mathrm{CH}_{4}$ and thus corresponding

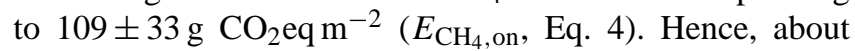
$1.25 \%$ of the ingested $\mathrm{C}$ became $\mathrm{CH}_{4}$ in the digestive process. Using this ratio led us to estimate another $2.4 \pm 0.6 \mathrm{~g}$ $\mathrm{C} \mathrm{m}^{-2}$ emitted as $\mathrm{CH}_{4}$ off-site, i.e. $3.2 \pm 0.8 \mathrm{~g} \mathrm{CH}_{4} \mathrm{~m}^{-2}$ or $80 \pm 20 \mathrm{~g} \mathrm{CO}_{2} \mathrm{eq} \mathrm{m}^{-2}\left(E_{\mathrm{CH}_{4} \text {,off }}\right)$. Subtracting the $\mathrm{C}$ emitted as $\mathrm{CH}_{4}$ on- and off-site from the respective digestible $\mathrm{C}$ ingested by sheep and other livestock led to $621 \pm 189 \mathrm{~g}$ $\mathrm{CO}_{2}$ eq m${ }^{-2}$ emitted on-site $\left(E_{\mathrm{CO}_{2}, \text { on }}\right)$ and $447 \pm 118 \mathrm{~g}$ $\mathrm{CO}_{2} \mathrm{eq} \mathrm{m}^{-2}$ emitted off-site. The sum of this latter emission value with the emissions expected from wheat ear use $\left(601 \pm 80 \mathrm{~g} \mathrm{CO}_{2} \mathrm{eq} \mathrm{m}^{-2}\right)$ gave a total off-site emission $\left(E_{\mathrm{CO}_{2} \text {,off }}\right)$ of $1048 \pm 143 \mathrm{~g} \mathrm{CO}_{2} \mathrm{eq} \mathrm{m}^{-2}$. In total, emissions were $1858 \pm 240 \mathrm{~g} \mathrm{CO}_{2} \mathrm{eq} \mathrm{m}^{-2}$ in 2 years $\left(F_{\mathrm{EXP}}\right.$, Eq. 4$)$.

For the SRC site, applying Eq. (5) with the diameter distribution led us to estimate AGWB (dry matter) as $0.62 \pm 0.29 \mathrm{~kg} \mathrm{~m}^{-2}$, which, with a C content of $49 \%$, corresponded to an $F_{\text {EXP }}$ of $1118 \pm 521 \mathrm{~g} \mathrm{CO}_{2}$ eq m$^{-2}$ in 2 years that is expected to be re-emitted to the atmosphere at combustion. This value of AGWB then corresponded to $8.1 \pm 3.7 \mathrm{MJ} \mathrm{m}^{-2}$ of gross energy from biomass chips, which decreased to $6.8 \pm 3.1 \mathrm{MJ} \mathrm{m}^{-2}$ of final heat obtainable from burning biomass chips when the conversion efficiency is con-

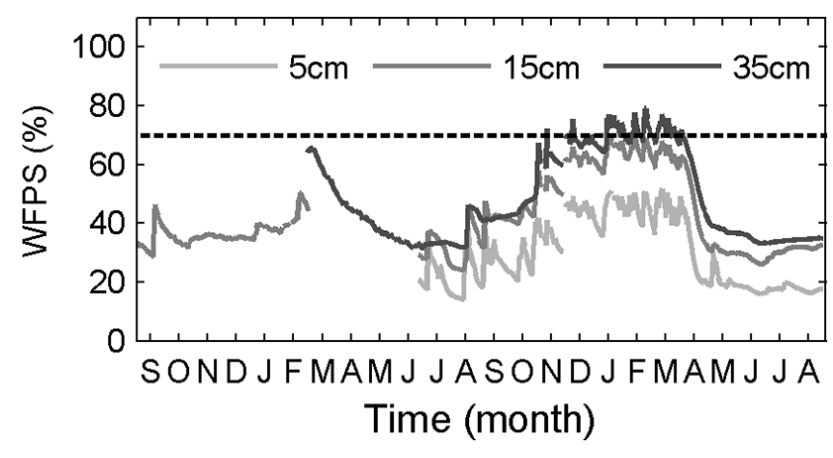

Figure 6. WFPS percentage at the REF site at three different depths for the 24-month integration periods. Dashed line indicates the threshold $(70 \%)$ above which $\mathrm{N}_{2} \mathrm{O}$ is released during lab incubation. First letter of month on the $x$ axis.

sidered. This could offset about $379.7 \pm 175.1 \mathrm{~g} \mathrm{CO}_{2} \mathrm{eq} \mathrm{m}^{-2}$ from final heat produced using natural gas.

\subsection{GHG budgets}

All the contributions reported in the previous sections were summed to calculate the GHG budgets of the two sites. The net GHG budget of the REF site ( $B_{\text {REF }}$, Eq. 2 ) amounted to $156 \pm 264 \mathrm{~g} \mathrm{CO}_{2} \mathrm{eq} \mathrm{m}^{-2}$, indicating that the REF site was close to neutrality from a GHG perspective, while for the SRC site, the $B_{\mathrm{SRC}}$ (Eq. 1) resulted in a cumulative sequestration of $-2202 \pm 792 \mathrm{~g} \mathrm{CO}_{2} \mathrm{eq} \mathrm{m}^{-2}$. The different components of the GHG budget of the two sites are summarized in Fig. 9. At the REF site, the $F_{\mathrm{CO}_{2}}$, weighing about $48 \%$ in the GHG budget, was completely compensated for by the emissions of $\mathrm{CO}_{2}$ and $\mathrm{CH}_{4}$ due to the biomass utilization (about 44 and $5 \%$ respectively), while the other components had a minor role $\left(F_{\mathrm{MAN}}\right.$ around $4 \%$, soil non- $\left.\mathrm{CO}_{2}<1 \%\right) . \mathrm{F}_{\mathrm{CO}_{2}}$ was the main contribution also at the SRC site, where it represented $63 \%$ of $B_{\mathrm{SRC}}$, while $F_{\mathrm{EXP}}$ represented $20 \%$. The SOC loss and the GHG offset for the fossil fuel substitution represented $8 \%$ and $7 \%$ respectively, while the other contributions played a minor role. As $B_{\mathrm{REF}}$ was almost neutral and the SRC site a sink of GHGs, the difference between the two GHG budgets was favourable at the SRC site $(2358 \pm 835 \mathrm{~g}$ $\mathrm{CO}_{2} \mathrm{eq} \mathrm{m}^{-2}$ saved), highlighting the advantages in terms of GHGs of the LUC from common agricultural land to SRC of poplar in the study area.

\section{Discussion}

The two ecosystems behaved differently in the measuring period: they were both characterized by a seasonal uptake of $\mathrm{CO}_{2}$ (Fig. 3), driven by the timing and duration of the growing season (in spring at the REF site and in summer at the SRC site). The peak of $\mathrm{CO}_{2}$ uptake was similar at both sites in 2012, while it was higher at the REF site in 2013. Periods with positive $\mathrm{CO}_{2}$ fluxes were longer at the REF site 


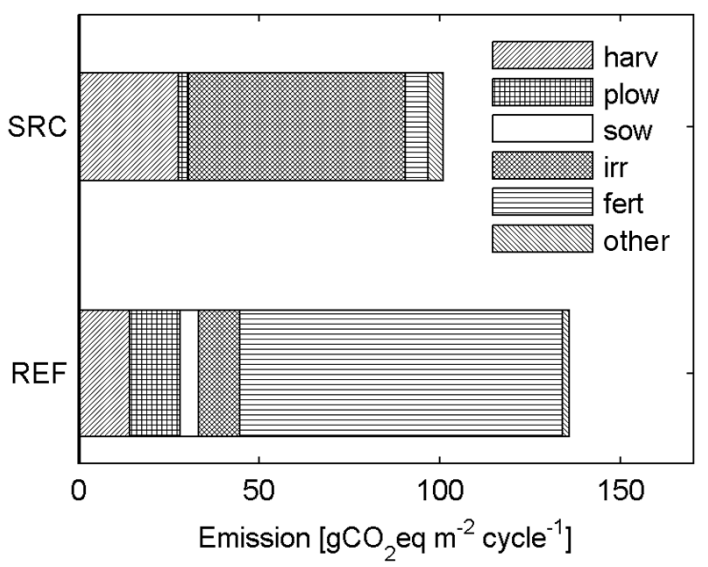

Figure 7. GHG emissions of the different farming operations. Harv: harvesting; plow: ploughing; sow: sowing; irr: irrigation; fert: fertilization; other: minor contributions. SRC and REF as previously defined.

and often higher in magnitude, likely as a consequence of the shorter growing season of grasses and winter wheat compared to the poplar trees of the SRC site. The land cover of the two sites during the dormant periods and the shift in time between them may also have played a role in this difference: some herbaceous vegetation continued to grow at the SRC site in wintertime, while harvesting and ploughing at the REF site in late summer and early fall may have enhanced ecosystem respiration. Interannual differences were also observed at both sites. Both the higher air temperature and the more extended period of low SWC proved the strong aridity of summer 2012, responsible for the autumnal increase in $\mathrm{CO}_{2}$ uptake at the SRC site, which corresponded to the rewetting of the soil. At the REF site, autumn uptake was higher in 2011, while the springtime uptake was much higher in 2013 than in 2012 (Fig. 3). This different behaviour was mostly ascribable to the different cultivations (grassland and winter wheat) and to some extent to the different climate conditions in springtime. All these differences in ecosystems responses resulted in a net sink of GHGs from the SRC site and in a neutral GHG balance for the REF site.

A GHG balance not significantly different from 0 is in agreement with the average results for a set of sites in Soussana et al. (2007), where, however, management costs were not considered and on-site $\mathrm{CO}_{2}$ emissions from grazing animals were measured with EC. $\mathrm{C}$ sequestered by the SRC site in our study was higher than that of the Belgian site in the study of Zona et al. (2013). In the latter study, the net budget was positive (for a time span of 1.5 years) with a net emission of $280 \pm 80 \mathrm{~g} \mathrm{CO}_{2} \mathrm{eq} \mathrm{m}^{-2}$, due to both the higher emission rates of $\mathrm{CH}_{4}$ and $\mathrm{N}_{2} \mathrm{O}$ fluxes from soil $\left(350 \pm 50 \mathrm{~g} \mathrm{CO}_{2}\right.$ eq m$\left.{ }^{-2}\right)$ and to the lower $\mathrm{CO}_{2}$ sink $\left(-80 \pm 60 \mathrm{~g} \mathrm{CO}_{2} \mathrm{eq} \mathrm{m}^{-2}\right)$ compared to the present study. Jassal et al. (2013) also found lower $F_{\mathrm{CO}_{2}}$ in a 3-year-old poplar SRC in Canada $\left(-293 \mathrm{~g} \mathrm{CO}_{2} \mathrm{~m}^{-2} \mathrm{yr}^{-1}\right)$ compared to the

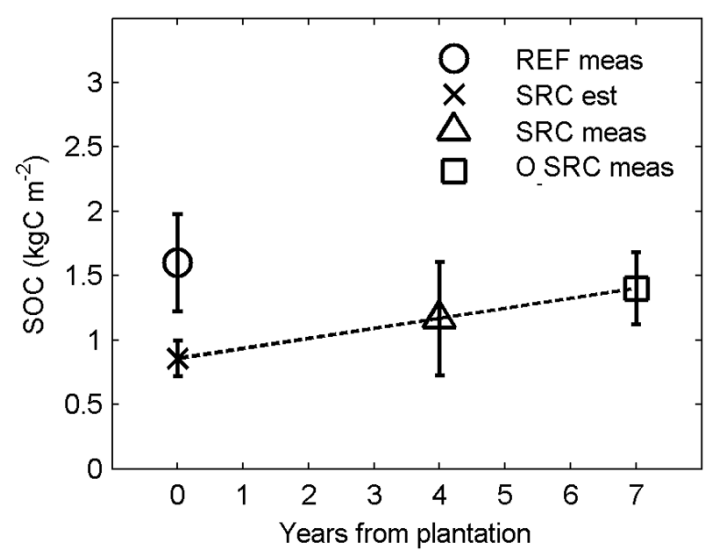

Figure 8. Regression line of SOC content in time $t$ (years). The gap between SOC $(0)$ and SOC content measured at the REF site represented the loss of SOC for the land use change. Est: estimated values; meas: measured values; SRC and REF as previously defined; O_SRC is the older short-rotation coppice site used to build the regression.

$F_{\mathrm{CO}_{2}}$ of the SRC site of the present study (root age: 4 years), likely due to the lower stem density of their site. All these values lay in the range found by Arevalo et al. (2011), i.e. -77 and $-4756 \mathrm{~g} \mathrm{CO}_{2} \mathrm{~m}^{-2} \mathrm{yr}^{-1}$ relative to a 2-year-old and 9-year-old poplar SRC respectively. These results show that even in a Mediterranean area, where plants are subjected to drought stress, there is the potential for a positive effect on climate mitigation with a proper use of irrigation.

Several studies (Grigal and Berguson, 1998; Price et al., 2009) confirmed that converting agricultural land to SRC resulted in an initial release of SOC due to SRC establishment and then in a slow and continuous accumulation of SOC due to vegetation activity and wood encroachment (Arevalo et al., 2011). Despite the deep tillage during SRC establishment and despite the fact that the REF site was ploughed every year at different depths, a gradient decreasing with depth in the $\mathrm{C}$ distribution of the vertical profile was evident at the three sites (not shown). This suggests that the changes in SOC were attributable to the plantation of the SRC only because of the effects of tillage (Anderson-Teixeira et al., 2009) and not to the mechanical redistribution of SOC. This study indicates an SOC loss of $47 \%$ compared to the value measured at the REF site, due to the installation of poplar cuttings. This loss was not measured at the time it occurred, i.e. right after the conversion of arable land to poplar short-rotation coppice, but was estimated with data from the O_SRC site. The reported value was close to the range maximum reported in the review by Post and Kwon $(2000 ; 20$ $50 \%$ ) but was higher than the results found by Arevalo et al. $(2011 ; 7 \%)$. The absolute value, however, was close to the one of this latter study $\left(8 \mathrm{Mg} \mathrm{Cha}^{-1}\right)$, where the initial SOC was 1 order of magnitude higher $\left(114.7 \mathrm{Mg} \mathrm{Cha}^{-1}\right)$. To correctly interpret this rapid loss of SOC for a conver- 
sion of a cropland to an SRC the low degree of disturbance that characterized the REF site must be taken into account. Furthermore, the loss of SOC found in the present study has to be considered along with its own uncertainty that was as large as the estimated value: for the purposes of the GHG balance, where the uncertainty of the single components are propagated to the net budget, this result is correctly interpreted as a range. We highlight that a loss of SOC close to the minimum of the abovementioned range by Post and Kwon (2000), e.g. $321 \mathrm{~g} \mathrm{C} \mathrm{m}^{-2}$, would have changed $B_{\mathrm{SRC}}$ $(-2202 \pm 792)$ by only $-259 \mathrm{~g} \mathrm{CO}_{2} \mathrm{eq} \mathrm{m}^{-2}$. Thus, even if a measured value would probably have been more accurate, the sensitivity of the total GHG budget to this loss was shown to be relatively low. The estimated annual SOC accumulation rate was in the range of that reported by Don et al. (2012) for SRCs $\left(0.44 \pm 0.43 \mathrm{Mg} \mathrm{Cha}^{-1} \mathrm{y}^{-1}\right)$, which explained how the frequent harvest of above-ground biomass was likely to facilitate the die-off of the roots that contributes to SOC accumulation. In our study, the low biomass yield supports the hypothesis that a large fraction of $\mathrm{C}$ taken up via photosynthesis was transferred to roots and soil. In our study the break-even point, where the initial SOC content would be restored and a net SOC accumulation would start, was 10 years, in agreement with findings from other studies (e.g. Hansen, 1993, and Arevalo et al., 2011, found a value of 7 years, while Grigal and Berguson, 1998, calculated a breakeven point of 15 years). This result, not directly involved in the 24-month GHG budget, is relevant, considering that the SRC of the present study is expected to be used for 12 years, thus enough to make the complete recovery of the SOC loss that occurred at the plantation possible. Different previous land uses, soil types (in particular clay content), climate conditions, fertilization rates may be the main causes of differences between studies, as shown in a meta-analysis by Laganière et al. (2010).

Our results showed that $\mathrm{CH}_{4}$ and $\mathrm{N}_{2} \mathrm{O}$ soil fluxes were not relevant in the GHG budgets due to the combination of soil characteristics and climatic trends at both sites. Low values are reported in other studies for SRCs: for example, Gauder et al. (2012) found that the soil of different energy crops acted as a weak sink of $\mathrm{CH}_{4}$ even in the case of fertilization, while emissions of $\mathrm{N}_{2} \mathrm{O}$ turned out to be higher for annual than for perennial (willow) crops, which showed no significant effect of fertilization on $\mathrm{N}_{2} \mathrm{O}$ fluxes. Agricultural sites usually have higher $\mathrm{N}_{2} \mathrm{O}$ effluxes from soil, though their magnitude depends on cultivations and on management practices, as shown by Ceschia et al. (2012). The SRC site as a perennial woody crop was subjected to low soil disturbance during its lifespan, while the REF site was ploughed once per year, which had an impact on the ecosystem respiration. Zona et al. (2013) found high $\mathrm{N}_{2} \mathrm{O}$ emissions in the first growing season of a poplar SRC in Belgium: $197 \pm 49 \mathrm{~g} \mathrm{CO}_{2} \mathrm{eq} \mathrm{m}^{-2}$ in 6 months, which drastically decreased to $42 \pm 17 \mathrm{~g} \mathrm{CO}_{2} \mathrm{eq} \mathrm{m}^{-2}$ for the whole following year. This suggested an influence of soil disturbance during land conversion on the stock of

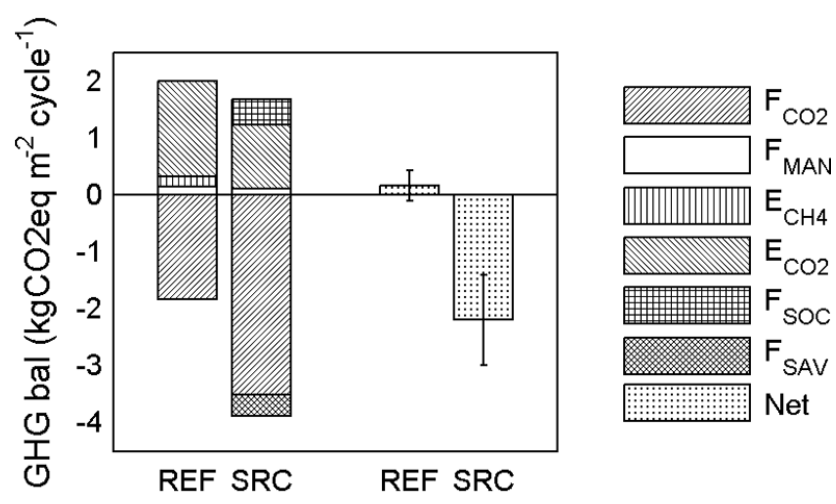

Figure 9. GHG balances of the SRC and the REF sites: components (left) and net (right). $F_{\mathrm{CH}_{4}}$ and $F_{\mathrm{N}_{2} \mathrm{O}}$ from soil are negligible and not included in the graph. $F_{\mathrm{MAN}}$ : management; $E_{\mathrm{CH}_{4}}$ : exported biomass re-emitted as $\mathrm{CH}_{4}$ by enteric fermentation; $E_{\mathrm{CO}_{2}}$ : exported biomass re-emitted as $\mathrm{CO}_{2}$ by sheep respiration; $F_{\mathrm{SOC}}$ : initial SOC change at the installation of cuttings; $F_{\mathrm{SAV}}$ : GHG savings for replacement of fossil fuel use; $F_{\mathrm{CO}_{2}}$ as previously defined.

$\mathrm{N}$ in soil, which was almost $1 / 3$ lower in our study sites than in that of Zona $\left(9.1 \pm 2.1 \mathrm{Mg} \mathrm{Nha}{ }^{-1}\right)$. In the present experiment, however, $\mathrm{N}_{2} \mathrm{O}$ fluxes were low both at the SRC and REF sites, even during periods of fertilization, with no clear patterns. The low $\mathrm{N}_{2} \mathrm{O}$ fluxes were confirmed by laboratory analyses, as the presence of extra $\mathrm{N}$ did not affect the emission rates of $\mathrm{N}_{2} \mathrm{O}$, and only very high WFPS percentage could trigger significant $\mathrm{N}_{2} \mathrm{O}$ fluxes. The conditions needed of soil humidity were never reached at the REF site and persisted only for a few days at $35 \mathrm{~cm}$ depth at the SRC site (Fig. 6). At this depth fertilizer was added as fertigation at the SRC site: we hypothesize that the very low porosity, the compaction, and the strength of the soil might have favoured slow gas release and further $\mathrm{N}_{2} \mathrm{O}$ reduction, thus leaving little $\mathrm{N}_{2} \mathrm{O}$ to escape to the atmosphere from soil surface. At the REF site, winter fertilization was also associated with low temperatures, a further constraint on microbial activity. These results provide further evidence of how the simple application of the IPCC $\mathrm{N}_{2} \mathrm{O}$ emission factor to the analysed systems might have led to an overestimation of the field GHG contribution to the overall GWP at both sites. Laboratory estimates of mineralization and nitrification rates suggested that $\mathrm{N}$ mineralization might be the limiting process of the chains of mineral $\mathrm{N}$ microbial transformations, which contributed to keeping $\mathrm{N}_{2} \mathrm{O}$ emissions low even during events of intense rainfall and soil saturation. The clay content and compaction of the analysed soils might be an important factor in limiting oxygen and substrate diffusion, which are both necessary to have optimal rates of soil organic matter mineralization. From a methodological point of view, the low emissions of both $\mathrm{CH}_{4}$ and $\mathrm{N}_{2} \mathrm{O}$ from soil also suggest that using four samples of gas concentration per chamber instead of three would not have dramatically improved the accuracy of the calculated fluxes, as a slight variation in 
the slope would have not induced significant changes in the results. The relevance of this result lies in the fact that fertilizing a poplar SRC in a Mediterranean area and in this kind of soil does not necessarily lead to increased emissions of $\mathrm{N}_{2} \mathrm{O}$, with the requirement that the correct equilibrium is found between irrigation and WFPS percentage. Thus, it is possible to maximize yield and GHG mitigation with the right management practices (Nassi o Di Nasso et al., 2010). $\mathrm{CH}_{4}$ and $\mathrm{N}_{2} \mathrm{O}$ fluxes might have been enhanced by the land conversion in the first period of cultivation of the SRC site, as found for $\mathrm{CO}_{2}$. However, measurements carried out at the REF site, ploughed every year, and the incubation experiment showed very low fluxes, mostly related to soil characteristics and not to management activities. Thus, a low sensitivity of the total GHG budget to these components can be expected.

Other components of the GHG budget related to N compounds (e.g. aerosol $\mathrm{NH}_{4} \mathrm{NO}_{3}, \mathrm{~N}$ deposition and leaching) were considered negligible in this study compared to the role of $\mathrm{N}_{2} \mathrm{O}$ emissions from soil and related to fertilizer production.

Regarding the use of biomass, comparisons with other studies for the REF site are complicated because half of the field was converted to sorghum in spring to compensate for the low productivity experienced during the drought. However, the productivity of a mixture of clover and ryegrass was found to be highly variable by Martiniello (1999), and the results of the present study are comparable with the lower values found by this author in non-irrigated stands in a Mediterranean climate $\left(0.39 \mathrm{~kg} \mathrm{~m}^{-2}\right)$. Sorghum productivity was lower than that reported by Nassi o Di Nasso et al. (2011; around $0.75 \mathrm{~kg} \mathrm{~m}^{-2}$ ) in a similar climate, likely due to the short period of cultivation and to grazing. The productivity of winter wheat was similar to that in Anthoni et al. (2004; $0.32 \pm 0.03 \mathrm{~kg} \mathrm{~m}^{-2}$ ). The drought in summer $2012 \mathrm{had}$ an important influence on the AGWB of the SRC site, which was lower compared to other studies (e.g. Scholz and Ellerbrock, 2002; 0.4 to $0.7 \mathrm{~kg} \mathrm{~m}^{-2} \mathrm{yr}^{-1}$ ) and to the $F_{\mathrm{CO}_{2}}$ values found with EC. Our hypothesis is that the period of drought influenced the above-ground/belowground ratio and that the herbaceous vegetation contributed to the increase in $F_{\mathrm{CO}_{2}}$. In terms of $\mathrm{C}$, the difference $F_{\mathrm{CO}_{2}}-F_{\mathrm{EXP}}$ represents, to a first approximation, the $\mathrm{C}$ stocked by each ecosystem that does not return shortly to the atmosphere after utilization minus heterotrophic respiration $(\mathrm{Rh})$. While at the SRC site that difference was negative ( $\mathrm{C}$ sink of $650 \mathrm{~g} \mathrm{C} \mathrm{m}^{-2}$ ), the REF site acted as a small source of $\mathrm{C}\left(120 \pm 98 \mathrm{~g} \mathrm{C} \mathrm{m}^{-2}\right)$. Small sources were also found by Anthoni et al. (2004; between $50 \mathrm{~g} \mathrm{C} \mathrm{m}^{-2}$ and $100 \mathrm{~g} \mathrm{C} \mathrm{m}^{-2}$ ), while Aubinet et al. (2009) reported a 4-year rotation crop as a source of $340 \mathrm{~g} \mathrm{C} \mathrm{m}^{-2}$. For poplar, Deckmyn et al. (2004) found a similar behaviour in a poplar SRC in Belgium. Concerning the fraction of the exports that is emitted as $\mathrm{CH}_{4}$ from enteric fermentation, our estimates were in agreement with those of Dengel et al. (2011). Several studies (e.g. Gilmanov et al., 2007) used $\mathrm{EC}$ to measure $\mathrm{CO}_{2}$ and $\mathrm{CH}_{4}$ fluxes from grazed systems.
Some included only $F_{\mathrm{CO}_{2}}, F_{\mathrm{CH}_{4}}$ and $F_{\mathrm{N}_{2} \mathrm{O}}$ in the GHG budget and created a $\mathrm{C}$ budget for lateral fluxes such as biomass export (e.g. Allard et al., 2007). However, the EC method is not capable of measuring point sources of trace gases moving inside and outside the footprint (data discarded by QA-QC (quality-assurance-quality-control) procedures: see also Baldocchi et al., 2012). Thus, we adapted the method described in Soussana et al. (2007) for off-site emissions, extending it also to on-site emissions, to include the effects of aboveground biomass use in the GHG budget.

Different studies (e.g. Cherubini et al., 2009; Djomo et al., 2013) confirmed the advantages of using biomass from SRC over fossil fuels in mitigating the increase in atmospheric GHG concentrations, while Abbasi and Abbasi (2010) found that the SRC management led to GHG emissions that compensate for the gain due to the fossil substitution. The low yield of the SRC site led to lower GHG savings compared to those found by Cherubini et al. (2009) for the production of heat from woody products $\left(379.7 \pm 175.1 \mathrm{~g} \mathrm{CO}_{2} \mathrm{eq} \mathrm{m}^{-2}\right.$ in 2 years compared to $600 \mathrm{~g} \mathrm{CO}_{2} \mathrm{eq} \mathrm{m}^{-2}$ per year). Cherubini et al. (2009) found GHG mitigation to be directly proportional to crop yield for dedicated bioenergy crops. From a GHG budget perspective, however, the yield is also proportional to $\mathrm{C}$ emissions from combustion and correlated with $\mathrm{F}_{\mathrm{CO}_{2}}$. The same study reported GHG savings of other bioenergy systems, showing that the performance of wood-based systems is lower in terms of GHG offset than that of other bioenergy crops, e.g. switchgrass $\left(1300 \mathrm{~g} \mathrm{CO}_{2} \mathrm{eq} \mathrm{m}^{-2} \mathrm{yr}^{-1}\right)$, Miscanthus $\left(1600 \mathrm{~g} \mathrm{CO}_{2} \mathrm{eq} \mathrm{m}^{-2} \mathrm{yr}^{-1}\right)$, and fibre sorghum $(1800 \mathrm{~g}$ $\mathrm{CO}_{2} \mathrm{eq} \mathrm{m}^{-2} \mathrm{yr}^{-1}$ ). In the present study the role of GHG offset was relevant in the GHG balance; however, it is important to consider that natural gas, while being the most used fossil fuel for heating systems in Italy, also has a lower carbon intensity for heat production (55.862 $\mathrm{g} \mathrm{CO}_{2} \mathrm{eq} \mathrm{MJ}^{-1}$ ) compared to coal (76.188 $\mathrm{g} \mathrm{CO}_{2} \mathrm{eq} \mathrm{MJ}^{-1}$ ) and oil (73.693 $\mathrm{g}$ $\mathrm{CO}_{2}$ eq $\mathrm{MJ}^{-1}$; Romano et al., 2014). A different scenario, where biomass would substitute the use of other energy sources with higher emission factors (such as coal) would lead to a higher GHG offset.

Our study confirmed that farming operations only have a limited importance in the overall GHG budget when the conditions of relevant $\mathrm{CO}_{2}$ uptake by vegetation are met, and the values we found were similar to the ones found by Gelfand et al. (2011). At the SRC site, irrigation was more important than other contributions and caused more emissions than irrigation at the REF site. This suggests that belowground irrigation was less efficient in terms of GHG emissions than the sprinkler. Fertilizers and other chemical products often have a higher impact on the GHG balance compared to other field operations due to the off-site GHG emissions (Ceschia et al., 2010). At the study sites the amount and frequency of applications were relatively small, and this explains the minor role of fertilization in the total GHG budget. Thus, the importance of farming operations can vary from year to year, depending on climate conditions and on farmer decisions. 
This study reports on the GHG budget of poplar SRC in Mediterranean areas. However, when considering the implications of SRC in a wider perspective, other factors should also be considered to assess the overall sustainability of this type of LUC. Among them, irrigation is one of the most important (Dougherty and Hall, 1995), as poplar cultivations in a Mediterranean climate require considerable amounts of water. In the LUC presented here, both the SRC and the REF sites were irrigated with similar amounts of water, using a less efficient technique at the REF site (sprinkler system) than at the SRC site (belowground drip system; e.g. Camp, 1998). The impact of the LUC on the local water balance is thus expected to be small in this particular case but not in general. An appropriate design of these systems is also crucial to avoid water dispersion: in the present study we observed that irrigation could not compensate for the drought stress experienced by the SRC site in 2012; thus, concerns arise regarding the proper location of the belowground tubes and regarding the amounts of water applied. The aim of this study was to analyse the LUC from a GHG perspective at a farm level. The boundary of our system constituted the main difference from a full LCA analysis, where the iLUC is considered in addition to the direct land use change. iLUC can cause GHG emissions elsewhere, thus reducing the mitigation potential of the studied SRC on a global scale.

\section{Conclusions}

This study analysed a land use change (LUC) for biomass production from a greenhouse gas (GHG) perspective. The conversion of a traditional cropland (REF site) to a shortrotation coppice (SRC site) of poplar hybrids in a Mediterranean climate (Central Italy) was considered. Different fluxes were included in a GHG budget calculated for both sites: those to and from vegetation and soil; those caused by management; those due to the loss of soil organic carbon (SOC) at the installation of the cuttings; caused by the use of the biomass and the displacement of GHG emissions from fossil fuel. Environmental aspects other than the GHG balance were not considered, such as the water balance, the minor components of the nitrogen cycle, and the contribution of the indirect land use change (iLUC: Djomo et al., 2013). The direct LUC contributions, such as the SOC content loss at the installation of the SRC and the corresponding disadvantages in terms of GHG, were instead included in the calculation.

Our study showed how poplar SRC cultivation for biomass production was overall suitable from the point of view of the climate change mitigation. The most important components of the GHG budgets were the net ecosystem exchange $\left(F_{\mathrm{CO}_{2}}\right)$ and the $\mathrm{C}$ export ( $\left.F_{\mathrm{EXP}}\right)$ at the end of the cultivation cycle. Interestingly, fluxes of $\mathrm{CH}_{4}$ and $\mathrm{N}_{2} \mathrm{O}$ from soil were not relevant, likely due to physical soil characteristics. No significant effects were observed even in the case of fertilization, irrigation or rain events, in contrast with findings from other stud- ies (e.g. Zona et al., 2013). Results demonstrated that poplar clones have the ability to stock high rates of $\mathrm{C}$ from the atmosphere even in a Mediterranean climate, where the cultivation of poplar SRC depends critically on water. The estimated uncertainty was, however, quite large, confirming the need for large efforts in terms of data collection to correctly estimate the different components. Benefits of the LUC from common agriculture to SRC derived from the interaction between the diverse components of the budget. Climate conditions and farmer needs are the most important factors controlling the single contributions of the GHG budget. An equilibrate combination of clone selection, irrigation, and management activities, depending also on soil properties, is thus crucial to achieve an efficient contribution to climate change mitigation by LUC for bioenergy crops.

Acknowledgements. This research was supported by the GHG Europe Project (EU Seventh Framework Programme, FP7) and the MIUR-PRIN project "Climate change mitigation strategies in tree crops and forestry in Italy" (CARBOTREES). The authors wish to acknowledge the technical employees of DIBAF (A. Baiocco, A. Boschi, M. Tomassucci), CNR IBAF (G. Santarelli), and CNR IBIMET (A. Zaldei) for their indispensable support and logistic help during the field campaign and the database staff (E. Canfora, A. Ribeca, D. Polidori, C. Trotta) for their support in the data post-processing. S. Sabbatini is supported by the ICOS-Inwire EU project, and S. Njakou Djomo was supported by the ERC Advanced Grant 233366 POPFULL. We further thank G. Parisi for gas chromatography analysis. We are also grateful to the farm Gisella ed Elena Ascenzi S.A.A.S. and in particular to A. Trani, the farmer who kindly allowed us to install our instruments on his fields and to access his farm whenever we needed it and who supported our scientific activities with his interest and availability. All the data collected are available at the European Ecosystem Fluxes Database at www.europe-fluxdata.eu, site codes IT-CA1, IT-CA2, and IT-CA3.

Edited by: A. Ibrom

\section{References}

Abbasi, T. and Abbasi, S. A.: Biomass energy and the environmental impacts associated with its production and utilization, Renew. Sust. Energ. Rev., 14, 919-937, 2010.

Allard, V., Soussana, J.F., Falcimagne, R., Berbigier, P., Bonnefond, J.M., Ceschia, E., D’hour, P., Hénault, C., Laville, P., Martin, C., and Pinarès-Patino, $\mathrm{C}$. : The role of grazing management for the net biome productivity and greenhouse gas budget $\left(\mathrm{CO}_{2}, \mathrm{~N}_{2} \mathrm{O}\right.$ and $\mathrm{CH}_{4}$ ) of semi-natural grassland, Agr. Ecosyst. Environ., 121, 47-58, 2007.

Alternative Fuels Data Center: Fuel properties comparison, available at: http://www.afdc.energy.gov/fuels/fuel_comparison_ chart.pdf (last access: 10 March 2015), 2014.

Anderson-Teixeira, K. J., Davis, S. C., Masters, M. D., and Delucia, E. H.: Changes in soil organic carbon under biofuel crops, Glob. 
Change Biol., 1, 75-96, doi:10.1111/j.1757-1707.2008.01001.x, 2009.

Anthoni, P., Freibauer, A., Kolle, O., and Schulze, E.: Winter wheat carbon exchange in Thuringia, Germany, Agr. Forest Meteorol., 121, 55-67, 2004.

Arevalo, C., Bhatti, J. S., Chang, S. X., and Sidders, D.: Land use change effects on ecosystem carbon balance: from agricultural to hybrid poplar plantation. Agr. Ecosyst. Environ., 141, 342-349, 2011.

Aubinet, M., Grelle, A., Ibrom, A., Rannik, Ü., Moncrieff, J., Foken, T., Kowalski, A.S., Martin, P.H., Berbigier, P., Bernhofer, C., Clement, R., Elbers, J., Granier, A., Grünwald, T., Morgenstern, K., Pilegaard, K., Rebmann, C., Snijders, W., Valentini, R., and Vesala, T.: Estimates of the annual net carbon and water exchange of forests: the EUROFLUX methodology, Adv Ecol Res, 30, 113-175, 2000.

Aubinet, M., Moureaux, C., Bodson, B., Dufranne, D., Heinesch, B., Suleau, M., Dufranne, D., Heinesch, B., Suleau, M., Vancutsem, F., and Vilret, A.: Carbon sequestration by a crop over a 4-year sugar beet/winter wheat/seed potato/winter wheat rotation cycle, Agr. Forest Meteorol., 149, 407-418, 2009.

Aubinet, M., Vesala, T., and Papale, D. (Eds.): Eddy covariance: a practical guide to measurement and data analysis, Springer, New York, USA, 438 pp., 2012.

Baldocchi, D., Detto, M., Sonnentag, O., Verfaillie, J., Teh, Y. A., Silver, W., and Kelly, N. M.: The challenges of measuring methane fluxes and concentrations over a peatland pasture, Agr. Forest Meteorol., 153, 177-187, 2012.

Barber, A.: Seven case study farms: total energy \& carbon indicators for New Zealand arable \& outdoor vegetable production, AgriLINK New Zealand Ltd, 288 pp., 2004.

Bechis, S. and Marangon, F.: Analisi delle emissioni di $\mathrm{CO}_{2}$ nelle diverse fonti energetiche, report, Department of Economy, Agricultural, Forest and Environmental Engineering, University of Turin, Italy, 38 pp., 2011.

Blasi, C.: Carta del fitoclima del Lazio. Regionalizzazione e caratterizzazione climatica, map, Regione Lazio, Assessorato Agricoltura e Foreste, Caccia e Pesca, Usi civici. Sapienza University, Dept of Vegetal Biology, Rome, 1993.

Boone, R. D., Grigal, D. F., Sollins, P., Ahrens, R. J., and Armstring, D. E.: Soil sampling, preparation, archiving, and quality control, in: Standard Soil methods for Long-term Ecological Research, edited by: Robertson, G. P., Coleman, D. C., Bledsoe, C. S., and Sollins, P., Oxford University Press, New York, 3-28, 1999.

Boundy, B., Diegel, S. W., Wright, S. W. L., and Davis, S. C.: Biomass energy data book: edition 4. Report \#ORNL/TM2011/446 by the Oak Ridge National Laboratory for the Office of the Biomass Program, US Department of Energy, Oak Ridge, Tennessee, 2011.

Byrne, K. A., Kiely, G., and Leahy, P.: Carbon sequestration determined using farm scale carbon balance and eddy covariance, Agr. Ecosyst. Environ., 121, 357-364, 2007.

Budsberg, E., Rastogi, M., Puettmann, M. E., Caputo, J., Balogh, S., Volk, T. A., Gustafson, R., and Johnson, L.: Life-cycle assessment for the production of bioethanol from willow biomass crops via biochemical conversion, Forest Prod. J., 62, 305-313, 2012.

Camp, C. R.: Subsurface drip irrigation: a review, Transactions of the ASAE, 41, 1353-1367, 1998.
Caputo, J., Balogh, S. B., Volk, T. A., Johnson, L., Puettmann, M., Lippke, B., and Oneil, E.: Incorporating uncertainty into a life cycle assessment (LCA) model of short-rotation willow biomass (Salix spp.) crops, BioEnerg. Res., 7, 48-59, 2014.

Castaldi, S. and Aragosa, D.: Factors influencing nitrification and denitrification variability in a natural and fire-disturbed Mediterranean shrubland, Biol. Fert. Soils, 36, 418-425, 2002.

Castaldi, S., Carfora, A., Fiorentino, A., Natale, A., Messere, A., Miglietta, F., and Cotrufo, M.F.: Inhibition of net nitrification activity in a Mediterranean woodland: possible role of chemicals produced by Arbutus unedo, Plant Soil, 315, 273-283, 2009.

Castaldi, S., Bertolini, T., Valente, A., Chiti, T., and Valentini, R.: Nitrous oxide emissions from soil of an African rain forest in Ghana, Biogeosciences, 10, 4179-4187, doi::10.5194/bg-104179-2013, 2013.

Ceschia, E., Béziat, P., Dejoux, J. F., Aubinet, M., Bernhofer, C., Bodson, B., Buchmann, N., Carrara, A., Cellier, P., Di Tommasi, P., Elbers, J. A., Eugster, W., Grünwald, T., Jacobs, C. M. J., Jans, W. W. P., Jones, M., Kutsch, W., Lanigan, G., Magliulo, E., Marloie, O., Moors, E. J., Moureaux, C., Olioso, A., Osborne, B., Sanz, M. J., Saunders, M., Smith, P., Soegaard, H., and Wattenbach, M.: Management effects on net ecosystem carbon and GHG budgets at European crop sites, Agr. Ecosyst. Environ., 139, 363-383, 2010.

Cherubini, F., Bird, N. D., Cowie, A., Jungmeier, G., Schlamadinger, B., and Woess-Gallasch, S.: Energy-and greenhouse gas-based LCA of biofuel and bioenergy systems: Key issues, ranges and recommendations, Resour. Conserv. Recy, 53, 434447, 2009.

Chesworth, W.: Encyclopedia of soil science. Encyclopedia of Earth Sciences Series, Springer, Dordrecht, the Netherlands, 902 pp., 2008.

Conen, F., Yakutin, V., and Sambuu, A. D.: Potential for detecting changes in soil organic carbon concentrations resulting from climate change, Glob. Change Biol., 9, 1515-1520, 2003

Crutzen, P. J., Mosier, A. R., Smith, K. A., and Winiwarter, W.: $\mathrm{N}_{2} \mathrm{O}$ release from agro-biofuel production negates global warming reduction by replacing fossil fuels, Atmos. Chem. Phys., 8, 389-395, doi:10.5194/acp-8-389-2008, 2008.

Davis, S. C., Anderson-Teixeira, K. J., and DeLucia, E. H.: Lifecycle analysis and the ecology of biofuels, Trends Plant. Sci., 14, 140-146, 2009.

Dengel, S., Levy, P. E., Grace, J., Jones, S. K., and Skiba, U. M.: Methane emissions from sheep pasture, measured with an openpath eddy covariance system, Glob. Change Biol., 17, 35243533, 2011.

Deckmyn, G., Muys, B., Garcia Quijano, J., and Ceulemans, R.: Carbon sequestration following afforestation of agricultural soils: comparing oak/beech forest to short-rotation poplar coppice combining a process and a carbon accounting model, Glob. Change Biol., 10, 1482-1491, 2004.

Dillen, S. Y., Djomo, S. N., Al Afas, N., Vanbeveren, S., and Ceulemans, R.: Biomass yield and energy balance of a short-rotation poplar coppice with multiple clones on degraded land during 16 years, Biomass Bioenerg., 56, 157-165, 2013.

Djomo, S. N., El Kasmioui, O., and Ceulemans, R.: Energy and greenhouse gas balance of bioenergy production from poplar and willow: a review, Glob. Change Biol., 3, 181-197, doi:10.1111/j.1757-1707.2010.01073.x, 2011. 
Djomo, S. N., El Kasmioui, O., De Groote, T., Broeckx, L. S., Verlinden, M. S., Berhongaray, G., Fichot, R., Zona, D., Dillen, S. Y., King, J. S., Janssens, I. A., and Ceulemans, R.: Energy and climate benefits of bioelectricity from low-input short rotation woody crops on agricultural land over a two-year rotation, Appl Energ, 111, 862-870, 2013.

Don, A., Osborne, B., Hastings, A., Skiba, U., Carter, M. S., Drewer, J., Flessa, H., Freibauer, A., Hyvönen, N., Jones, M. B., Lanigan, G. J., Mander, Ü., Monti, A., Djomo, S. N., Valentine, J., Walter, K., Zegada-Lizarazu, W., and Zenone, T.: Land-use change to bioenergy production in Europe: implications for the greenhouse gas balance and soil carbon, Glob. Change Biol., 4, 372-391, 2012.

Dong, H., Mangino, J., and McAllister, T. A.: Emissions from livestock and manure management, in: 2006 IPCC Guidelines for National Greenhouse Gas Inventories, Prepared by the National Greenhouse Gas Inventories Programme edited by: Eggleston, $\mathrm{H}$. S., Buendia, L., Miwa, K., Ngara, T., and Tanabe, K., Hayama, Japan, 10.1-10.89., 2006.

Dougherty, T. C. and Hall, A. W.: Environmental impact assessment of irrigation and drainage projects, Irrigation and Drainage Paper 53, FAO, Rome, 74, 1995.

Edwards, R., Larivé, J. F., Mahieu, V., and Rouveirolles, P.: Well-towheels analysis of future automotive fuels and powertrains in the European context, Tank-to-Wake Report Version 2c, EUCAR, CONCAWE, \& JRC, Ispra, Italy, 182 pp., 2007.

El Kasmioui, O. and Ceulemans, R.: Financial analysis of the cultivation of poplar and willow for bioenergy, Biomass Bioenerg., 43, 52-64, 2012.

El Kasmioui, O. and Ceulemans, R.: Financial Analysis of the Cultivation of Short Rotation Woody Crops for Bioenergy in Belgium: Barriers and Opportunities, BioEnerg. Res., 6, 336-350, 2013.

European Commission: Renewable energy road map - renewable energies in the 21st century: building a more sustainable future, $\operatorname{COM}(2006) 848$ final, Brussels, Belgium, 20 pp., 2007.

European Commission: 2020 by 2020 - Europe's climate change opportunity. COM(2008) 30, Brussels, Belgium, 12 pp., 2008.

European Commission: Directive 2009/28/Ec Of The European Parliament And Of The Council of 23 April 2009 on the promotion of the use of energy from renewable sources and amending and subsequently repealing Directives 2001/77/EC and 2003/30/EC Official Journal of the European Union, L 140/16-62, EU, Brussels, Belgium, 2009.

Fargione, J., Hill, J., Tilman, D., Polasky, S., and Hawthorne, P.: Land clearing and the biofuel carbon debt, Science, 319, 1235 1238, 2008.

Fisher, R.: The Correlation between Relatives on the Supposition of Mendelian Inheritance, T. Rse. Earth, 52, 399-433, 1919.

Foken, T.: Micrometeorology, edited by: Nappo C. J., Springer Verlag, Berlin-Heidelberg, Germany, 308 pp., 2008.

Forster, P., Ramaswamy, V., Artaxo, P., Berntsen, T., Betts, R., Fahey, D. W., Haywood, J., Lean, J., Lowe, D. C., Myhre, G., Nganga, J., Prinn, R., Raga, G., Schulz, M., and Van Dorland, R.: Changes in Atmospheric Constituents and in Radiative Forcing, in: Climate Change 2007: The Physical Science Basis. Contribution of Working Group I to the Fourth Assessment Report of the Intergovernmental Panel on Climate Change, edited by: Solomon, S., Qin, D., Manning, M., Chen. Z., Marquis, M., Averyt, K. B., Tignor, M., and Miller, H. L., Cambridge University
Press, Cambridge, United Kingdom and New York, NY, USA, 129-234, 2007.

Gash, J. H. C. and Culf, A. D.: Applying a linear detrend to eddy correlation data in realtime, Bound.-Lay. Meteorol., 79, 301306, 1996.

Gauder, M., Butterbach-Bahl, K., Graeff-Hönninger, S., Claupein, W., and Wiegel, R.: Soil-derived trace gas fluxes from different energy crops-results from a field experiment in Southwest Germany, Glob. Change Biol., 4, 289-301, 2012.

Gelfand, I., Zenone, T., Jasrotia, P., Chen, J., Hamilton, S. K., and Robertson, G. P.: Carbon debt of Conservation Reserve Program (CRP) grasslands converted to bioenergy production, P. Natl. Acad. Sci. USA, 108, 13864-13869, 2011.

Gielen, B., De Vos, B., Campioli, M., Neirynck, J., Papale, D., Verstraeten, A., Ceulemans, R., and Janssens, I. A.: Biometric and eddy covariance-based assessment of decadal carbon sequestration of a temperate Scots pine forest, Agr. Forest Meteorol., 174, 135-143, 2013.

Gilmanov, T. G., Soussana, J. F., Aires, L., Allard, V., Ammann, C., Balzarolo, M., Barcza, Z., Bernhofer, C., Campbell, C. L., Cernusca, A., Cescatti, A., Clifton-Brown, J., Dirks, B. O. M., Dore, S., Eugster, W., Fuhrer, J., Gimeno, C., Gruenwald, T., Haszpra, L., Hensen, A., Ibrom, A., Jacobs, A. F. G., Jones, M. B., Lanigan, G., Laurila, T., Lohila, A., Manca, G., Marcolla, B., Nagy, Z., Pilegaard, K., Pinter, K., Pio, C., Raschi, A., Rogiers, N., Sanz, M. J., Stefani, P., Sutton, M., Tuba, Z., Valentini, R., Williams, M. L., and Wohlfahrt, G.: Partitioning European grassland net ecosystem $\mathrm{CO}_{2}$ exchange into gross primary productivity and ecosystem respiration using light response function analysis, Agr. Ecosyst. Environ., 121, 93-120, 2007.

Goodman, L. A.: On the exact variance of products, J. Am. Stat. Assoc., 55, 708-713, 1960.

Grigal, D. F. and Berguson, W. E.: Soil carbon changes associated with short-rotation systems, Biomass Bioenerg., 14, 371-377, 1998.

Gundersen, P., Christiansen, J. R., Alberti, G., Brüggemann, N., Castaldi, S., Gasche, R., Kitzler, B., Klemedtsson, L., Lobo-doVale, R., Moldan, F., Rütting, T., Schleppi, P., Weslien, P., and Zechmeister-Boltenstern, S.: The response of methane and nitrous oxide fluxes to forest change in Europe, Biogeosciences, 9, 3999-4012, doi:10.5194/bg-9-3999-2012, 2012.

Hansen, E.: Soil carbon sequestration beneath hybrid poplar plantations in the north central United States, Biomass Bioenergy, 5, 431-436, 1993.

Ibrom, A., Dellwik, E, Flyvbjerg, H., Jensen, N. O., and Pilegaard, K.: Strong low-pass filtering effects on water vapour flux measurements with closed-path eddy correlation systems, Agric. Forest Meteorol., 147, 140-156, 2007.

Italian Ministry of Interior: Bilancio energetico nazionale 2012, Dipartimento per l'energia, Direzione generale per la sicurezza dell'approvvigionamento e le infrastrutture energetiche, available at: http://dgerm.sviluppoeconomico.gov.it/dgerm/ben.asp, (last access: 25 February 2015), 2013.

IUSS Working Group WRB: World Reference Base for Soil Resources 2014, International soil classification system for naming soils and creating legends for soil maps, World Soil Resources Reports, 106, FAO, Rome, Italy, 181 pp., 2014.

Jassal, R. S., Black, T.A., Arevalo, C., Jones, H., Bhatti, J. S., and Sidders, D.: Carbon sequestration and water use of a young hy- 
brid poplar plantation in north-central Alberta, Biomass Bioenerg., 56, 323-333, 2013.

Jaoudé, R. A., Lagomarsino, A., and De Angelis, P.: Impacts of nitrogen fertilisation and coppicing on total and heterotrophic soil $\mathrm{CO}_{2}$ efflux in a short rotation poplar plantation, Plant Soil, 339, 219-230, 2011.

Jungmeier, G. and Spitzer, J.: Greenhouse gas emissions of bioenergy from agriculture compared to fossil energy for heat and electricity supply, Nutr. Cycl. Agroecosys., 60, 267-273, 2001.

Kandeler, E.: Nitrification during long term incubation, in: Methods in soil biology, edited by: Schinner, F., Kandeler, E., Ohlinger, R., and Margesin, R., Springer, Berlin Heidelberg New York, USA, 149-151, 1996.

Laganiere, J., Angers, D. A., and Pare, D.: Carbon accumulation in agricultural soils after afforestation: a meta-analysis. Glob. Change Biol., 16, 439-453, 2010.

Latium Region, Regional Direction of Agriculture and Rural Development, Hunting and Fishing: Rural Development Program of Latium 2007-2013, Reg. (CE) n. 1698/05, Rome, available at: http://www.agricoltura.regione.lazio.it/psr/programma/ ?vms=5\&ref=Il-testo-integrale-psr, last access: 20 October 2015.

Liu, Y., Langer, V., Høgh-Jensen, H., and Egelyng, H.: Life cycle assessment of fossil energy use and greenhouse gas emissions in Chinese pear production, J. Clean. Prod., 18, 1423-1430, 2010.

Marble, S. C., Prior, S. A., Runion, G. B., Torbert, H. A., Gilliam, C. H., Fain, G. B., Sibley, J. L., and Knight, P. R.: Trace gas emissions from nursery crop production using different fertilization methods, Acta Hortic., 1014, 401-405, 2013.

Mareschi, L.: Piantagioni da bioenergia: sostenibilita' produttiva ed ambientale di nuovi cloni ibridi di pioppo (Populus spp.), Ph.D. thesis, University of Tuscia, Italy, 142 pp., 2008.

Martiniello, P.: Effects of irrigation and harvest management on dry-matter yield and seed yield of annual clovers grown in pure stand and in mixtures with graminaceous species in a Mediterranean environment, Grass. Forage. Sci., 54, 52-61, 1999.

Migliavacca, M., Meroni, M., Manca, G., Matteucci, G., Montagnani, L., Grassi, G., Zenone, T., Teobaldelli, M., Goded, I., Colombo, R., and Seufert, G.: Seasonal and interannual patterns of carbon and water fluxes of a poplar plantation under peculiar eco-climatic conditions, Agr. Forest Meteorol., 149, 1460-1476, 2009.

Mikutta, R., Kleber, M., Kaiser, K., and Jahn, R.: Review: Organic Matter Removal from Soils using Hydrogen Peroxide, Sodium Hypochlorite, and Disodium Peroxodisulfate, Soil Sci. Soc. Am. J., 6, 120-135, 2005.

Mitchell, C. P., Stevens, E. A., and Watters, M. P.: Short-rotation forestry - operations, productivity and costs based on experience gained in the UK, Forest Ecol. Manag., 121, 123-136, 1999.

Moncrieff, J. B., Massheder, J. M., De Bruin, H., Elbers, J., Friborg, T., Heusinkveld, B., Kabat, P., Scotta, S., Soegaard, H., and Verhoef, A.: A system to measure surface fluxes of momentum, sensible heat, water vapour and carbon dioxide, J. Hydrol., 188, 589-611, 1997.

Nassi o Di Nasso, N., Guidi, W., Ragaglini, G., Tozzini, C., and Bonari, E.: Biomass production and energy balance of a 12-yearold short-rotation coppice poplar stand under different cutting cycles, Glob. Change Biol., 2, 89-97, 2010.
Nassi o Di Nasso, N., Bosco, S., Di Bene, C., Coli, A., Mazzoncini, M., and Bonari, E.: Energy efficiency in long-term Mediterranean cropping systems with different management intensities, Energy, 36, 1924-1930, 2011.

Osborne, B., Saunders, M., Walmsley, D., Jones, M., and Smith, P.: Key questions and uncertainties associated with the assessment of the cropland greenhouse gas balance, Agr. Ecosyst. Environ., 139, 293-301, 2010.

Pearson, K.: On the criterion that a given system of deviations from the probable in the case of a correlated system of variables is such that it can be reasonably supposed to have arisen from random sampling, The London, Edinburgh, and Dublin Philosophical Magazine and Journal of Science, 50, 157-175, 1900.

Papale, D., Reichstein, M., Aubinet, M., Canfora, E., Bernhofer, C., Kutsch, W., Longdoz, B., Rambal, S., Valentini, R., Vesala, T., and Yakir, D.: Towards a standardized processing of Net Ecosystem Exchange measured with eddy covariance technique: algorithms and uncertainty estimation, Biogeosciences, 3, 571-583, doi:10.5194/bg-3-571-2006, 2006.

Paris, P., Mareschi, L., Sabatti, M., Pisanelli, A., Ecosse, A., Nardin, F., and Scarascia-Mugnozza, G.: Comparing hybrid Populus clones for SRF across northern Italy after two biennial rotations: Survival, growth and yield, Biomass Bioenerg., 35, 1524-1532, 2011.

Pihlatie, M., Pumpanen, J., Rinne, J., Ilvesniemi, H., Simojoki, A., Hari, P., and Vesala, T.: Gas concentration driven fluxes of nitrous oxide and carbon dioxide in boreal forest soil, Tellus B, 59, 458469, 2007.

Post, W. and Kwon, K.: Soil carbon sequestration and land-use change: processes and potential, Glob. Change Biol., 6, 317-328, 2000.

Price, D., Orchansky, A., Jassal, R., Arevalo, C., and Thomas, B.: Soil respiration in a hybrid poplar plantation located in central Alberta, Alberta Soil Science Workshop 2009, Edmonton, Alberta, CA, 2009.

Reichstein, M., Falge, E., Baldocchi, D., Papale, D., Aubinet, M., Berbigier, P., Bernhofer, C., Buchmann, N., Gilmanov, T., Granier, A., Grünwald, T., Havránková, K., Ilvesniemi, H., Janous, D., Knohl, A., Laurila, T., Lohila, A., Loustau, D., Matteucci, G., Meyers, T., Miglietta, F., Ourcival, J.M., Pumpanen, J., Rambal, S., Rotenberg, E., Sanz, M., Tenhunen, J., Seufert, G., Vaccari, F., Vesala, T., Yakir, D., and Valentini, R.: On the separation of net ecosystem exchange into assimilation and ecosystem respiration, review and improved algorithm, Glob. Change Biol., 11, 1424-1439, 2005.

Robertson, G. P., Paul, E. A., and Harwood, R. R.: Greenhouse gases in intensive agriculture: contributions of individual gases to the radiative forcing of the atmosphere, Science, 289, 19221925, 2000.

Romano, D., Arcarese, C., Bernetti, A., Caputo, A., Cóndor, R. D., Contaldi, M., De Lauretis, R., Di Cristofaro, E., Gagna, A., Gonella, B., Lena, F., Liburdi, R., Taurino, E., and Vitullo, M.: Italian Greenhouse Gas Inventory 1990-2012, National Inventory Report 2014, ISPRA - Institute for Environmental Protection and Research, Rome, 507 pp., 2014.

Saidur, R., Abdelaziz, E. A., Demirbas, A., Hossain, M. S., and Mekhilef, S.: A review on biomass as a fuel for boilers, Renew. Sust. Energ. Rev., 15, 2262-2289, 2011. 
Scholz, V. and Ellerbrock, R.: The growth productivity, and environmental impact of the cultivation of energy crops on sandy soil in Germany, Biomass Bioenerg., 23, 81-92, 2002.

Smith, P., Lanigan, G., Kutsch, W. L., Buchmann, N., Eugster, W., Aubinet, M., Ceschia, E., Béziat, P., Yeluripati, J. B., Osborne, B., Moors, E. J., Brut, A., Wattenbach, M., Saunders, M., and Jones, M.: Measurements necessary for assessing the net ecosystem carbon budget of croplands, Agr. Ecosyst. Environ., 139, 302-315, 2010.

Soussana, J. F., Allard, V., Pilegaard, K., Ambus, P., Amman, C., Campbell, C., Ceschia, E., Clifton-Brown, J., Czobel, S., Domingues, R., Flechard, C., Fuhrer, J., Hensen, A., Horvath, L., Jones, M., Kasper, G., Martin, C., Nagy, Z., Neftel, A., Raschi, A., Baronti, S., Rees, R.M., Skiba, U., Stefani, P., Manca, G., Sutton, M., Tuba, Z., and Valentini, R.: Full accounting of the greenhouse gas $\left(\mathrm{CO}_{2}, \mathrm{~N}_{2} \mathrm{O}, \mathrm{CH}_{4}\right)$ budget of nine European grassland sites, Agr. Ecosyst. Environ., 121, 121-134, 2007.

Soussana, J. F., Tallec, T., and Blanfort, V.: Mitigating the greenhouse gas balance of ruminant production systems through carbon sequestration in grasslands, Animal, 4, 334-350, 2010.

Strauss, C. H. and Grado, S. C.: Economics of producing Populus biomass for energy and fiber systems, in: Micropropagation, genetic engineering, molecular biology of Populus, edited by: Klopfenstein, N. B., Chun, Y. W., Kim, M.-S., and Ahuja, M. R., USDA Forest Service, Fort Collins, CO, Rocky Mountain Forest and Range Experiment Station, 241-248, 1997.
Vickers, D. and Mahrt, L.: Quality control and flux sampling problems for tower and aircraft data, J. Atmos. Ocean Tech., 14, 512526, 1997.

Webb, E. K., Pearman, G. I., and Leuning, R.: Correction of flux measurements for density effects due to heat and water vapour transfer, Q. J. Roy. Meteor. Soc., 106, 85-100, 1980.

Weslien, P., Kasimir Klemedtsson, A., Börjesson, G., and Klemedtsson, L.: Strong pH influence on $\mathrm{N}_{2} \mathrm{O}$ and $\mathrm{CH}_{4}$ fluxes from forested organic soils, Eur. J. Soil. Sci., 60, 311-320, 2009.

Wilczak, J. M., Oncley, S. P., and Stage, S. A.: Sonic anemometer tilt correction algorithms, Bound.-Lay. Meteorol., 99, 127-150, 2001.

Wood, S. W. and Cowie, A.: A review of greenhouse gas emission factors for fertiliser production, International Energy Agency Bioenergy Task 38, 1-20, 2004.

Zhou, J., Zhang, Z., Sun, G., Fang, X., Zha, T., McNulty, S., Chen, J., Jin, Y., and Noormets, A.: Response of ecosystem carbon fluxes to drought events in a poplar plantation in Northern China, Forest Ecol. Manag., 300, 33-42, 2013.

Zona, D., Janssens, I.A., Aubinet, M., Vicca, S., Gioli, B., Fichot, R., and Ceulemans, R.: Fluxes of the greenhouse gases $\left(\mathrm{CO}_{2}\right.$, $\mathrm{CH}_{4}$ and $\mathrm{N}_{2} \mathrm{O}$ ) above a short-rotation poplar plantation after conversion from agricultural land, Agr. Forest Meteorol., 169, 100 110,2013 